\title{
Genetic, management, and nutritional factors affecting intramuscular fat deposition in beef cattle $-\mathrm{A}$ review
}

\author{
Seung Ju Park ${ }^{1, a}$, Seok-Hyeon Beak ${ }^{1, a}$, Da Jin Sol Jung ${ }^{1}$, Sang Yeob Kim¹, In Hyuk Jeong ${ }^{1}$, Min Yu Piao', \\ Hyeok Joong Kang ${ }^{1}$, Dilla Mareistia Fassah', Sang Weon Na ${ }^{1}$, Seon Pil Yoo ${ }^{1}$, and Myunggi Baik, ${ }^{1,2, *}$
}

\begin{abstract}
* Corresponding Author: Myunggi Baik Tel: +82-2-880-4809, Fax: +82-2-873-2271,

E-mail: mgbaik@snu.ac.kr
\end{abstract}

'Department of Agricultural Biotechnology and Research Institute of Agriculture and Life Sciences, College of Agriculture and Life Sciences, Seoul National University, Seoul 08826, Korea

2 Institutes of Green Bio Science Technology, Pyeongchang 25354, Korea

a These authors contributed equally to this work.

ORCID

Seung Ju Park

https://orcid.org/0000-0003-2035-2698

Seok-Hyeon Beak

https://orcid.org/0000-0003-4550-5937 Da Jin Sol Jung

https://orcid.org/0000-0002-9892-5698 Sang Yeob Kim

https://orcid.org/0000-0001-9296-8964 In Hyuk Jeong

https://orcid.org/0000-0002-5217-4649 Min Yu Piao

https://orcid.org/0000-0002-7067-7741 Hyeok Joong Kang

https://orcid.org/0000-0003-0732-1598

Dilla Mareistia Fassah

https://orcid.org/0000-0003-4309-9218

Sang Weon $\mathrm{Na}$

https://orcid.org/0000-0001-5529-653X

Seon Pil Yoo

https://orcid.org/0000-0001-8177-8241

Myunggi Baik

https://orcid.org/0000-0001-8373-9772

Submitted Apr 19, 2018; Revised May 4, 2018 ; Accepted May 10, 2018

\begin{abstract}
Intramuscular fat (IMF) content in skeletal muscle including the longissimus dorsi muscle (LM), also known as marbling fat, is one of the most important factors determining beef quality in several countries including Korea, Japan, Australia, and the United States. Genetics and breed, management, and nutrition affect IMF deposition. Japanese Black cattle breed has the highest IMF content in the world, and Korean cattle (also called Hanwoo) the second highest. Here, we review results of research on genetic factors (breed and sex differences and heritability) that affect IMF deposition. Cattle management factors are also important for IMF deposition. Castration of bulls increases IMF deposition in most cattle breeds. The effects of several management factors, including weaning age, castration, slaughter weight and age, and environmental conditions on IMF deposition are also reviewed. Nutritional factors, including fat metabolism, digestion and absorption of feed, glucose/starch availability, and vitamin A, D, and C levels are important for IMF deposition. Manipulating IMF deposition through developmental programming via metabolic imprinting is a recently proposed nutritional method to change potential IMF deposition during the fetal and neonatal periods in rodents and domestic animals. Application of fetal nutritional programming to increase IMF deposition of progeny in later life is reviewed. The coordination of several factors affects IMF deposition. Thus, a combination of several strategies may be needed to manipulate IMF deposition, depending on the consumer's beef preference. In particular, stage-specific feeding programs with concentrate-based diets developed by Japan and Korea are described in this article.
\end{abstract}

Keywords: Beef Cattle; Intramuscular Fat Deposition; Genetic Factors; Management; Nutrition

\section{INTRODUCTION}

Intramuscular fat (IMF) deposition or marbling in muscle including the longissimus thoracis et lumborum, infraspinatus, and biceps femoris, especially in Korean cattle (also called Hanwoo) and Japanese Black cattle, is one of the most important traits influencing beef quality and palatability attributes. Marbling is positively correlated with juiciness, tenderness, and palatability of beef [1]. For example, beef with higher IMF produces higher sensory traits, including tenderness, juiciness, flavor, and overall acceptability in Korean cattle [2] and in USA beef samples [3]. Most marbling fat is deposited between muscle fibre bundles in the perimysial connective tissue in beef cattle [4]. Marbling adipocytes are also found within muscle bundles in the longissimus dorsi muscle (LM) of high-quality grade Japanese Black cattle [5]. The production of highly marbled beef in Korea is essential to compete with cheap imported beef that has a relatively low marbling score (MS).

Several countries, including Korea, Japan, Australia and the USA, have considered IMF 
content as important to beef quality grade (QG), whereas European countries, including France and Germany, prefer leaner meat (less IMF content). Understanding the factors affecting IMF deposition and the mechanisms responsible for its deposition is important when manipulating IMF deposition. Our laboratory has studied IMF deposition for more than a decade to understand the mechanisms responsible for IMF deposition in beef cattle [6-12], and we have reviewed molecular mechanisms responsible for IMF deposition in cattle [13].

In this review, we first provide an overview of muscle and fat cell growth in ruminants. Factors affecting IMF deposition can be sub-categorized into genetic (breed and sex differences, heritability), management (weaning age, castration, slaughter weight and age, and environment), and nutritional factors (fat metabolism, fat digestion and absorption, glucose/starch availability, roughage vs concentrate ratio, dietary energy and protein levels, vitamins $\mathrm{A}, \mathrm{D}$, and C levels, fetal and neonatal nutritional programming, and stage-specific feeding systems). Here, we also review these factors affecting IMF deposition in cattle.

\section{OVERVIEW OF MUSCLE AND FAT CELL GROWTH IN RUMINANTS}

Skeletal muscle including the LM mainly consists of skeletal muscle fibres (myofibres), but it also contains fat cells, connective tissue or extracellular matrix, and various other cell types including satellite cells, immune cells and blood vessels. The ratio of muscle to fat cells varies depending on the amount of IMF deposited. Muscle and fat cell growth typically occur as mass increases due to both hyperplasia (increase in cell number) and hypertrophy (increase in cell size) $[14,15]$. It is important to identify the mechanisms responsible for initial muscle and fat cell growth during the developmental stage of cattle to better understand IMF deposition in later life. Muscle and fat cell development are dependent on myogenesis (muscle cell formation) and adipogenesis (fat cell formation), respectively [16]. The process of skeletal muscle and adipose tissue development during the fetal stage in laboratory animals and livestock including ruminants has been well described in reviews by Du et al [16-18]. Du et al [16] proposed that myogenic, adipogenic, and fibrogenic cells are derived from common mesenchymal progenitor cells. Briefly, they proposed that mesenchymal stem cells are first committed to the myogenic and adipogenic-fibrogenic cell lineages during fetal muscle development [16]. Then, myogenic progenitor cells further develop into muscle fibres and satellite cells, while adipogenicfibrogenic progenitor cells develop into the stromal-vascular fraction of skeletal muscle, where adipocytes, fibroblasts, and resident adipogenic-fibrogenic progenitor cells reside [16]. Du et al [17] suggested that a shift in development of mesenchy- mal stem cells from myogenesis to adipogenesis may increase IMF deposition later in life.

Adipogenesis is a comprehensive term that includes commitment of mesenchymal stem cells to preadipocytes, determination and proliferation of preadipocytes, and differentiation of preadipocytes into mature adipocytes [19]. Adipogenesis normally begins around mid-gestation in ruminant animals [20]. Differentiation of adipogenic cells occurs during fetal and postnatal stages. In the fetal stage, the main process is increasing the number of adipocytes (hyperplasia) derived from adipogenic-fibrogenic progenitor cells [21]. It has been suggested that adipocyte formation in muscle begins approximately between late gestation and $250 \mathrm{~d}$ after birth in cattle [16]. Hyperplasia of fat cells mainly occurs from conception until birth, and hypertrophy is a greater contributor to IMF deposition than is hyperplasia from $250 \mathrm{~d}$ of age to slaughter [16,17]. Both hyperplasia and hypertrophy are involved in IMF deposition (Figure 1). Therefore, strategies that up-regulate both hyperplasia and hypertrophy of fat cells are effective ways to improve IMF deposition.

After birth, the adipogenic-fibrogenic progenitor cells remain on some parts of the stromal vascular cells in adipose tissue, later serving as precursors to preadipocytes and adipocytes $[16,22]$. The nutritional and physiological condition of the fetus and the early postnatal stage affects the number of adipocytes in adipose tissues of animals [16]. Thus, managing maternal nutrition is a potentially effective way to promote adipogenesis in fetal muscle [16]. Du et al [17] suggested that the order of effectiveness of nutritional management for manipulating IMF deposition is fetal stage $>$ neonatal stage $>$ weaning stage $>$ older stages. Harper and Pethick [23] recommended that producers focus on individuals with high genetic capacity to create more preadipocytes within animal muscle. Then, preadipocytes can differentiate during the finishing stage when they fill with lipid to grow into visible marbling by hypertrophy. Albrecht et al [24] reported that hyperplasia of preadipocytes also plays an important role in marbling formation during postnatal growth of IMF because new marbling flecks appear after recruitment and filling with preadipocytes.

Four major adipose tissue depots exist in animals: abdominal, subcutaneous, intermuscular, and intramuscular. Adipogenesis in beef cattle is first initiated in abdominal (visceral) adipocytes around mid-gestation [16]. According to $\mathrm{Du}$ et al [16], this adipogenesic phase extends to the neonatal period for abdominal adipocytes, to the early weaning stage for subcutaneous and intermuscular adipocytes, and to around $250 \mathrm{~d}$ of age for IMF. Thus, during the late fattening stage of beef cattle, marbling adipocytes may grow continuously even though development of abdominal, intermuscular, and subcutaneous fat may slow or cease. 


\section{Hyperplasia : increase in fat cell number}

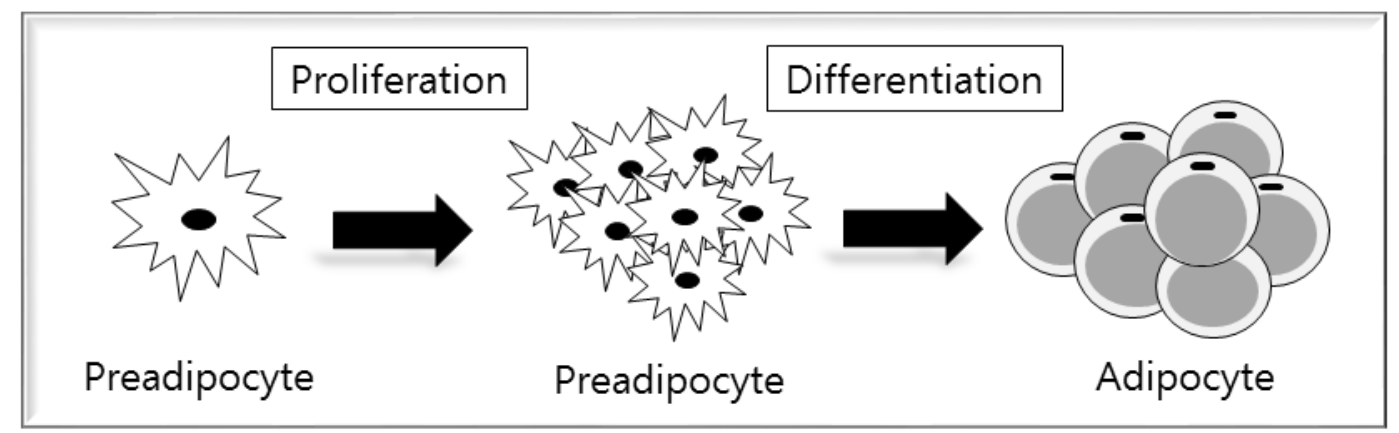

\section{Hypertrophy : increase in fat cell size}

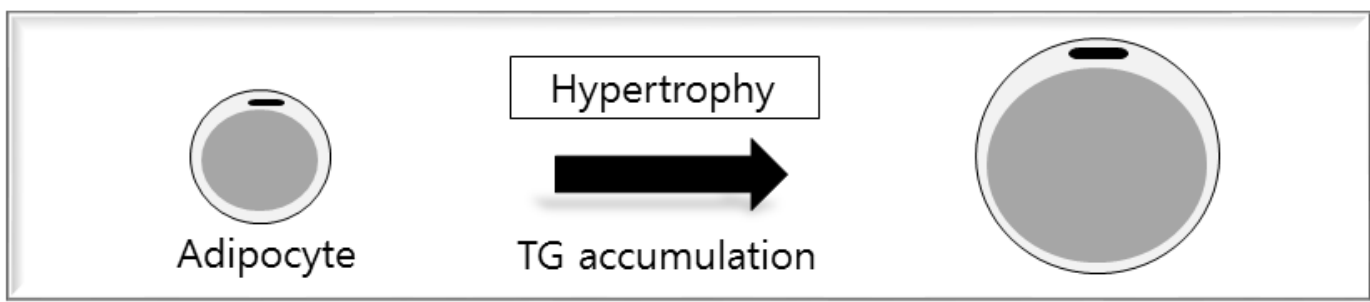

Figure 1. Intramuscular fat deposition through increased cell proliferation (hyperplasia) and cell size (hypertrophy). Increases in the number of fat cells normally occur at the early stage of animal growth through determination and proliferation of pre-adipocyte into adipocytes. The size of fat cells normally increases in response to triacylglycerol (TG) accumulation at a later stage of animal growth. Modified from Esteve Ràfols [161].

\section{GENETIC FACTORS}

\section{Breed and sex differences}

Intramuscular fat content in the LM varies significantly depending on the cattle breed. The LM of Wagyu contains the highest fat content (36.5\%: average value from two publications $[25,26])$, and the LM from Korean cattle contains the second highest fat content worldwide (13.7\%: average value from four publications [10,27-29]), followed by Angus (9.3\%: average value from three publications [30-32]), Hereford crossbred or Hereford (7.6\%: average value from two publications $[30,33])$, and Brahman (2.8\%: average value from four publications [32,34-36]) (Table 1). Bos taurus cattle generally have higher marbling and better tenderness than do Bos indicus animals

Table 1. Intramuscular fat contents in several cattle breeds

\begin{tabular}{|c|c|c|c|c|c|c|c|c|c|}
\hline Breed & $\begin{array}{c}\text { No. of } \\
\text { animals }\end{array}$ & Feeding system & Sex & $\begin{array}{l}\text { Slaughter age } \pm \text { SE } \\
\text { (mo) }\end{array}$ & $\begin{array}{l}\text { Slaughter wt } \pm \text { SE } \\
(\mathrm{kg})\end{array}$ & $\begin{array}{c}\text { Carcass wt } \pm \text { SE } \\
(\mathrm{kg})\end{array}$ & $\begin{array}{c}\text { Intramuscular } \\
\text { fat } \pm \text { SE } \\
(\%)\end{array}$ & $\begin{array}{l}\text { Muscle } \\
\text { type }\end{array}$ & Reference \\
\hline Wagyu & 6 & feedlot-concentrate & Steer & 26.0 & $640 \pm 19$ & $393 \pm 13$ & $34.3 \pm 1.7$ & LT & {$[25]$} \\
\hline Wagyu & 10 & feedlot-concentrate & Cow & 22.0 & $701 \pm 17.1$ & $444 \pm 11.9$ & $37.8 \pm 1.00$ & $\mathrm{LT}$ & {$[26]$} \\
\hline $\mathrm{KC}$ & 41 & feedlot-concentrate & Steer & $28.7 \pm 1.15$ & $682 \pm 71.6$ & $397 \pm 48.9$ & $13.3 \pm 4.40$ & LD & {$[10]$} \\
\hline $\mathrm{KC}$ & 10 & NP & Cow & $22.8-44.4$ & NP & NP & $14.3 \pm 0.43$ & $\mathrm{LL}$ & {$[27]$} \\
\hline $\mathrm{KC}$ & 20 & feedlot-concentrate & Steer & 31.7 & 752 & 459 & 15.3 & $\mathrm{LT}$ & {$[28]$} \\
\hline $\mathrm{KC}$ & 77 & feedlot-concentrate & Steer & $27.0-30.0$ & $N P$ & 370 & 13.5 & LD & {$[29]$} \\
\hline Angus & 10 & FS or $S S^{1)}$ & Steer & 27.5 & $N P$ & NP & 14.7 & $\mathrm{LL}$ & {$[30]$} \\
\hline Angus & 450 & feedlot-concentrate & Steer & $N P$ & 610 & $330 \pm 1.9$ & $6.2 \pm 0.21$ & LT & [31] \\
\hline Angus & 9 & feedlot-concentrate & Steer & NP & NP & NP & 7.1 & LD & [32] \\
\hline Hereford & 10 & FS or $S^{11}$ & Steer & 27.5 & $N P$ & $N P$ & 8.3 & $\mathrm{LL}$ & {$[30]$} \\
\hline Hereford crossbred & 228 & Pasture-grain & Not specified & 30.0 & 678 & 382 & 6.9 & LD & {$[33]$} \\
\hline Brahman & 7 & feedlot-concentrate & Steer & NP & $N P$ & $N P$ & 3.1 & LD & {$[32]$} \\
\hline Brahman & 10 & feedlot-silage, forage & Bull and cow & 29.0 & 399 & 234 & 2.8 & $\mathrm{LT}$ & {$[34]$} \\
\hline Brahman & 10 & feedlot-grass & Bull and cow & $24.0-30.0$ & 272 & 148 & 1.9 & LD & {$[35]$} \\
\hline Brahman & 50 & Grazing & Steer & 31.0 & 500 & $N P$ & 3.4 & LD & {$[36]$} \\
\hline
\end{tabular}

SE, standard errors; KC, Korean cattle; NP, not provided; LD, longissimus dorsi; LT, longissimus thoracis; LL, longissimus lumborum.

${ }^{1)} \mathrm{FS}$ or $\mathrm{SS}=$ a forage-only system (FS) or a forage with high-energy supplemented system (SS). 
$[1,37]$.

Sex affects IMF content in the LM. Castrating bulls generally increases IMF content in several breeds, including Korean cattle and Holstein [9,38-40]. In Korean cattle, Park et al [39] compared marbling degree by sex (bulls, steers, and cows), and steers had the best MS, followed by cows.

\section{Heritability}

Heritability of the marbling trait has been reported in several cattle breeds. Utrera and Van Vleck [41] presented estimates of heritability for cattle carcass traits in 72 studies (1962 through 2004). They reported that the average breed type list included purebred or crossbred Angus, Brahman, Simmental, Charolais, Hereford, Jersey, Korean Brown cattle, Maine Anjou, Pinzgauer, Sahiwal, Salers, and South Devon with estimates MS heritability of 0.37 (range 0.30 to 0.57 ). MS heritability is relatively high in Korean cattle ( 0.57 in Yoon et al [42]; 0:64 in Park et al [43]). The heritability marbling phenotype in Japanese Wagyu is 0.40 to 0.55 [44-46], and MS heritabilities in Angus and Brahman are 0.48 [47] and 0.37 to 0.44 [48,49], respectively. The genetic potential of individual cattle can significantly affect IMF deposition. Greenwood et al [30] conducted a study to test effects of genotypes and nutrition during the immediate postweaning period on IMF contents in 5 muscles, marbling, and subcutaneous fat (rib fat or P8 rump fat) in Bos Taurus steers. The study was conducted with steer of three genotypes (Angus, Hereford and Wagyu $\times$ Angus): Angus was targeting high IMF and high subcutaneous fat, Hereford was targeting low IMF and high subcutaneous fat, and Wagyu sires Angus dams were targeting high IMF and lower subcutaneous fat. Following weaning, steers were grown with a forage-only system and forage with high-energy supplemented system to test effects of a highenergy grain-based substitution on fat deposition with 5 times serial slaughter. In their study, genotype differences were generally observed in IMF contents of 4 muscles (biceps femoris, supraspinatus, semitendinosus, longissimus lumborum, and infraspinatus), although semitendinosus muscle IMF did not differ among genotypes. The $\mathrm{P} 8$ rump fat depth was generally greater in Hereford than Angus, and Meat Standard Australia (MSA) MS was generally lower in Hereford than in Angus and Wagyu $\times$ Angus. However, substitution of equivalent amount of energy from grazed pasture with high-energy grain-based feed has not increased IMF contents. Selecting a sire is important for high-quality beef production; animals with high genetic potential will generally exhibit higher MS at slaughter age, whereas animals with low genetic potential will give low MS [50].

\section{MANAGEMENT FACTORS}

Several management factors, including weaning age, castration, slaughter age and weight, nutrition and other environmental conditions can affect IMF deposition.

\section{Weaning age}

Weaning age is known to affect IMF deposition and MS in beef. Several studies have reported that early weaning or early weaning combined with a high-grain diet increases IMF deposition in beef cattle. In two separate studies, early-weaned steers (weaned at $177 \mathrm{~d}$ [study 1] and $158 \mathrm{~d}$ [study 2] of age and placed on a finishing diet) increased MS and body weight gain, improved feed efficiency, and improved QG of the beef compared with normally weaned steers or normally weaned steers supplemented with grain [51]. In these studies, the normally weaned steers remained on pasture during nursing and weaning at $231 \mathrm{~d}$ (study 1) and $213 \mathrm{~d}$ of age (study 2), respectively, and they were then placed on a finishing diet. The steers of the normally weaned steers supplemented with grain were raised under the same conditions as the normally weaned animals, but they were supplemented with grain for $55 \mathrm{~d}$ on pasture (study 1, 177 to $231 \mathrm{~d}$ of age; study 2, 158 to $213 \mathrm{~d}$ of age). Effect of weaning age has been studied in Shorthorn calves [52]. In their study, early weaning calves (123 d of age; $145 \mathrm{~kg}$ of body weight) were compared with conventional weaning animals ( $259 \mathrm{~d}$ of age; $273 \mathrm{~kg}$ of body weight) in contemporary feeding management. Early weaned- animals showed lighter final body weight, and tended to eat less than conventionally weaned- animals. However, weaning treatment did not affect feed efficiency, post weaning growth, MS, and other carcass traits. Another study in Angus and Wagyu cross heifers raised under early weaning (142 days old) and accelerated finishing programs on a high concentrate diet showed increased IMF and greater weight gain compared with heifers weaned at $180 \mathrm{~d}$ of age and grown on pasture for 16 months before entering the feedlot [53]. In the Angus study, early weaning at $105 \mathrm{~d}$ of age and high concentrate feeding for $148 \mathrm{~d}$ followed by grazing and feedlot entry increased both the MS and hot carcass weight (HCW) compared with normal weaning at $253 \mathrm{~d}$ of age (normally weaned calves stayed with their dams to graze on pasture), although feedlot performance remained unchanged [54]. The authors suggested that metabolic imprinting by early weaning and a high concentrate feeding before grazing is a feasible method to improve MS and carcass weight.

A study was performed to understand the mechanism responsible for improved MS after early weaning and highconcentrate feeding in Angus and Angus $\times$ Simmental steers [55]. Early weaning (141 d of age) followed by a high-starch diet improved MS compared with normal weaning $(222 \mathrm{~d}$ of age) followed by a starch creep-feed diet. A molecular study revealed that early weaning and a high-starch diet activated precocious pre-adipocyte differentiation and fat accumulation by activating adipogenic peroxisome proliferator-activated 
receptor-gamma (PPARG) and CCAAT/enhancer-binding protein a pathways. In another study, Graugnard et al [56] reported that a high-starch diet induced precocious upregulation of the adipogenic gene network in the longissimus lumborum of early-weaned (average 155 d) Angus cattle. Smith and Johnson [57] suggested that the glucose contribution to fat synthesis decreases as cattle become fatter, whereas acetate use increases, especially in the IMF area. Those authors also suggested that providing dietary glucose sources (e.g., high-starch diet) at an early age can improve IMF deposition. Two-week-old Korean cattle calves were fed different diets, i.e., mother's milk+roughage (control), milk replacement+concentrate, milk replacement+concentrate+roughage, and milk replacement+ concentrate $+30 \%$ starch [58]. All calves were then fed the same diet for 22 months, and muscle tissues were collected by biopsy. The RNA-Seq transcriptome and KEGG pathway analyses of differentially expressed genes showed that pathways for PPAR signaling, regulation of the actin cytoskeleton, biosynthesis of unsaturated fatty acids (FA), and Wnt signaling changed in the milk replacement+concentrate+roughage group compared with those in the control group, whereas the milk replacement+concentrate $+30 \%$ starch diet group showed changes in insulin signaling and mTOR signaling pathways. The milk re placement+concentrate+roughage group and the milk replacement+concentrate group showed changes in the adipokine signaling pathway compared to control group. The authors suggested that feeding concentrate plus roughage or starch after early weaning at a young age could alter adipogenic and lipogenic potential in loin meat.

\section{Castration}

Castration of bulls generally increases IMF content in several cattle breeds, although it reduces growth rate [40]. Castration of bulls profoundly increased MS, QG, and IMF contents in Korean cattle [9,39]. The castration rate of bulls has been increasing in Korea in the 21st century, and it was about 95\% in 2013 [59]. Five QG levels are used in the Korean beef QG system [QG1++ (highest), QG1+, QG1, QG2, and QG3 (lowest)] [59]. A 2016 report of nationwide pooled data in Korean cattle revealed that the majority (76\%) of bulls had a QG 3, whereas $85.5 \%$ of castrated cattle showed grades of QG 1 or higher (QG1, QG1+, and QG1++) ([59]; Figure 2). Castration also increased MS in Canadian beef carcasses [60]. Japanese Black cattle bulls are normally castrated to get highly marbled beef in Japan [61]. Castration is also known to increase tenderness in several cattle breeds, including Korean cattle [62], Angus and Angus-Hereford cross breeds [63], and Brahman and Charolais cross breeds [64].

\section{Slaughter age}

IMF content increases with increasing age in most cattle breeds. The IMF content in the LM of somatic-cell-cloned Japanese black steers increased with age at slaughter: 20 (23.7\%), 25 (38.7\%), and 30 months (41.1\%) [65]. Purebred Japanese Black cattle show a linear increase in IMF content with increasing slaughter age from 16.7 months $(500 \mathrm{~d}$ ) to over 33.3 months $(1,000 \mathrm{~d})$ [66]. MS increased with increasing slaughter age from 16.2 months ( $485 \mathrm{~d}$ ) to 20.3 months $(610 \mathrm{~d})$ in HolsteinFriesian and Norwegian dairy breeds [67]. In Angus, Hereford, and Wagyu $\times$ Angus, the IMF contents in the 5 muscles (biceps femoris, supraspinatus, semitendinosus, longissimus lumborum, and infraspinatus) and MSA MS increased with the increasing slaughter stages $(0,168,326,431$ and $585 \mathrm{~d}$ after weaning) [30]. Both MS and IMF contents increased with increasing

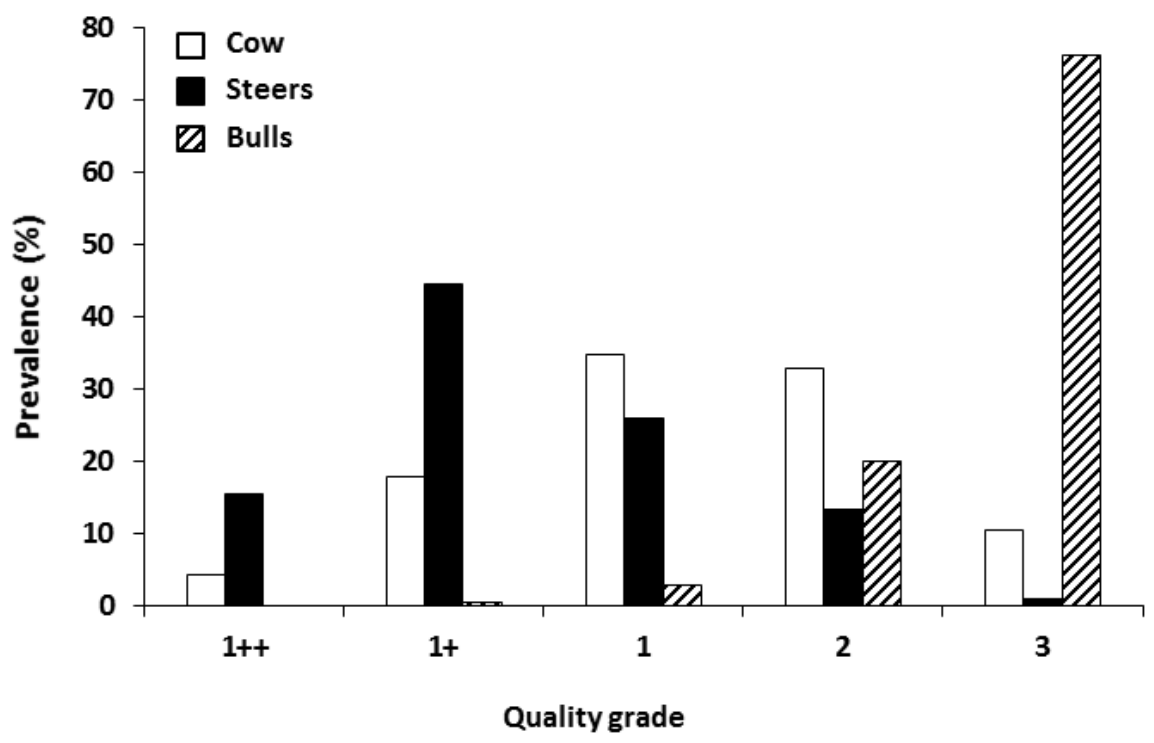

Figure 2. Comparison of quality grade percentages among sexes of Korean cattle in 2016. Cow $(n=353,880)$, steers ( $n=363,332)$, bulls $(n=20,264)$. Data source: Korea Institute for Animal Products Quality Evaluation [59]. 
slaughter age $(2,4,6,12$, and 24 months) in bulls of German Angus, Galloway, and Holstein-Friesian breeds [24]. However, these changes with slaugther age were not observed in doublemuscled Belgian Blue bulls [24].

The MS generally increases with slaughter age in Korean cattle. The MS standard ranges from 1 to 9 in Korea [59]. The MS of Korean cattle steers ( 81 animals) raised at the Livestock Improvement Main Center of the National Agricultural Cooperative Federation in Korea increased from 6.0 to 7.06 as slaughter age increased from 26 to 31 months [68]. The highest profit in this steer group was for a slaughter age of 31 months. In the same report [68], the MS in 5,826 Korean cattle steers from several farms in Gangwon Province was analyzed in 2010 to 2012; MS increased from 4.9 to 5.7 as slaughter age increased from 26 to 35 months. In this case, the optimum slaughter age for the highest profit was 28 months. This study suggested that changes in MS with slaughter age vary among farms. The difference may be due to genetic factors, management, or feed. Decreasing slaughter age may be better for reducing production costs when feed prices are high.

Pethick et al [69] suggested that a prolonged feeding period gives the cattle time to obtain high IMF levels because time is needed for muscle to reach maturity, followed by time for the muscle to fill up with IMF. However, feed efficiency decreases as animals age due to a decrease in the rate of muscle growth [70]. Thus, animals with low genetic potential for QG are not recommended for a long fattening stage, which would result in low feed efficiency. In addition, a long fattening period could result in low yield grade (YG) because long-term fattening increases backfat thickness and carcass weight, which negatively affect YG in Korean cattle [59]. Slaughter age needs to be optimised to get maximum profits for farmers by monitoring the QG and quantity grade of carcasses, feed costs, and carcass prices (auction prices).

\section{Slaughter weight}

IMF content or MS generally increases with slaughter weight in several cattle breeds. The National Beef Quality Audit of the USA (beef of steers and heifers in 28 packing plants during October-December 1991) found that MS increased with increasing slaugher weight from 173 to over $543 \mathrm{~kg}$ [71]. A linear increase in IMF content was observed in British and Japanese Black $\times$ Holstein-type cattle during a long fattening period in a feedlot, as carcass weight increased from 200 to $400 \mathrm{~kg}$ (reviewed in Pethick et al [69]). The MS and IMF content in Angus steers increases in a linear fashion with increasing HCW from 208 to $380 \mathrm{~kg}$ [72]. In the same study, LM area also increased linearly with increasing HCW. The IMF of Angus steers grown in South Dakota (USA) increased linearly with increasing HCW from 189 to $368 \mathrm{~kg}$ (live weight from 340 to $591 \mathrm{~kg}$ ) [73]. In pooled data of different sexes (cows, bulls, and steers) of Korean cattle, MS and LM area increased with in- creasing carcass weight from 143 to $536 \mathrm{~kg}$ [39]. IMF contents in the 5 muscles (biceps femoris, supraspinatus, semitendinosus, longissimus lumborum, and infraspinatus) also increased along with the increase of HCW at 5 slaughter stages in Angus (from 114.8 to $459.1 \mathrm{~kg}$ ), Hereford (from 114.0 to $452.2 \mathrm{~kg}$ ), and Wagyu $\times$ Angus (from 116.8 to $459.2 \mathrm{~kg}$ ) [30].

Feed efficiency decreases as animal age and slaughter weight exceed a certain level. Several factors, including MS or QG, feed costs, and carcass prices need to be considered to determine the optimum slaughter weight for the maximum profit.

\section{Environments}

Studies have demonstrated that environmental conditions, such as temperature stress, can negatively affect animal growth and beef quality in cattle [74]. In particular, exposing feedlot animals to hot or cold stress reduces growth and feed efficiency [75]. Cold stress during winter decreases animal performance and production efficiency [76,77]. Our recent study indicated that a lower ambient temperature decreased growth and feed efficiency in Korean cattle steers [78]. Heat stress can also negatively affect animal performance, including growth, milk production, reproduction, feed intake, overall health, and well-being in cattle $[79,80]$.

British and British $\times$ Continental crossbred cattle grown with no shelter or windbreak had greater fat thickness and MS in winter than did animals fed in a protected area [74]. The authors suggested that mild heat stress in summer and mild cold stress in winter may be beneficial to fat deposition under ad libitum feeding conditions for cattle fed in an unprotected, unsheltered area. They also suggested that animals deposit fat in the winter to provide insulation for the body under cold stress. Animals may require more energy to meet the increased maintenance energy requirements. Young [81] suggested that energy requirements increase during winter or when animals are under cold stress, as increased heat production is needed to maintain body temperature by shivering or other thermogenic process. Angus crossbred cattle exposed to greater heat stress tend to have a greater MS [82]. The authors mentioned that slight heat stress might induce IMF deposition. Seasonal variations in carcass characteristics have been observed in Korean cattle steers by our group [2]. The YG was lowest in winter and highest in spring and summer. In contrast, backfat thickness, which is a negative YG factor, was highest in winter. Therefore, the poor YG in winter may be due, in part, to high backfat thickness. However, both MS and QG were best in autumn and worst in spring. In same study, neither MS nor QG was associated with air temperature. Our recent study also revealed that growth performance was not affected by mild heat stress in Korean cattle [83]. Overall, severe temperature stress may have significant negative effects on animal production, including growth performance and product quality, although mild temperature stress may differentially affect 
production.

\section{NUTRITIONAL FACTORS}

Several nutritional factors including fat metabolism, fat digestion and absorption, glucose/starch availability, roughage vs. concentrate ratio, dietary energy and protein levels, vitamins $\mathrm{A}, \mathrm{D}$, and $\mathrm{C}$ levels, fetal nutritional programming, and stagespecific feeding systems can affect IMF deposition.

Fat synthesis and degradation metabolism

IMF deposition results from a balance among uptake, synthesis, and degradation of triglycerides (TGs). TG synthesis is a key factor for IMF deposition [69]. Both non-esterified fatty acids (NEFAs) and a glycerol backbone are required for TG synthesis. The FA de novo synthesis occurs mainly in adipose tissue in ruminants [84], whereas it occurs in the liver in humans and rodents. FA for TG synthesis is derived from de novo synthesis or diet-originating FAs.

The de novo FA synthesis pathway of ruminants is summarized in Figure 3. Acetate or glucose is used as a substrate for FA synthesis [85]. The predominant substrate for FA synthesis in ruminants is acetate, which is mainly derived from ruminal fermentation. Glucose can also be used as a substrate for FA de novo synthesis in ruminants. Glucose is derived from either glucose synthesis via gluconeogenesis from propionate/ lactate or glucose absorbed from the small intestinal digestion of the rumen bypass [86]. ATP citrate and NADP malate dehydrogenase are two key enzymes utilizing glucose in the FA de novo synthesis pathway. The activity of ATP citrate lyase is known to be low in ruminants [87]; thus, glucose is used as a lipogenic substrate less in ruminants than in monogastric animals [87]. However, glucose is believed to be preferred to acetate as a substrate for FA synthesis for IMF deposition [88]. These two enzymes are induced in adipose tissues of ruminants by increasing energy intake [89]. In addition, IMF has higher ATP-citrate lyase activity compared to subcutaneous fat [90]. Furthermore, IMF has a higher expression of glucose transporter 4, which is responsible for uptake of glucose in adipose tissues, compared to subcutaneous fat (reviewed in [90]). Using an in vitro system of adipose tissue from Angus and Wagyu steers, Rhoades et al [91] reported that the rate of glucose incorporation into FA was over two times higher than the rate of acetate incorporation into IMF, although they were similar in subcutaneous fat. The same authors suggested that feeding a corn-based diet increased glucose uptake in IMF, whereas feeding a hay-based diet may promote subcutaneous fat deposition via incorporation of acetate into FAs.

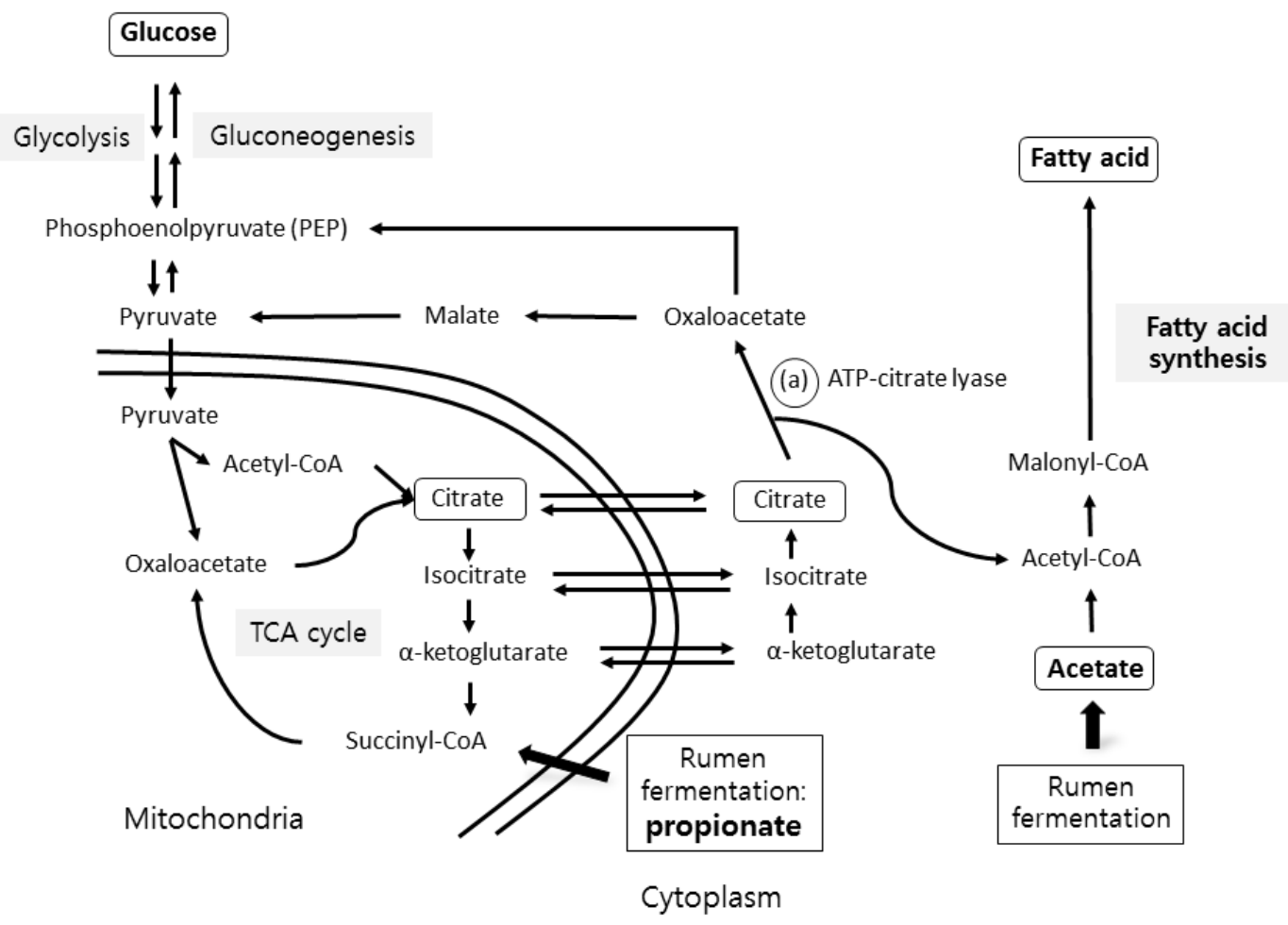

Figure 3. Fatty acid (FA) synthesis pathway in ruminants. Microbes ferment polysaccharide into volatile fatty acids such as acetate, propionate, and butyrate in the rumen. The acetate and propionate can contribute for FA synthesis. Acetate is converted to acetyl-CoA in the cytoplasm of ruminant cells and is used to synthesize FA. Propionate is transported into mitochondria where it enters the tricarboxylic acid cycle via succinyl-CoA and can be utilized as a substrate for the production of glucose via gluconeogenesis. Glucose, which is synthesized from propionate or rumen-bypassed and absorbed in the small intestine, can generate citrate in the tricarboxylic acid cycle, where it can be transported into the cytosol. The citrate in the cytosol is degraded into oxaloacetate and acetyl-CoA by ATP-citrate lyase, and the acetyl-CoA can be used to synthesize FAs. Modified from Bauman et al [162]. 
Fatty acids of dietary origin are obtained from transportation of TG lipoprotein and subsequent uptake after lipoprotein lipase hydrolysis into tissues from the circulation [92,93]. Fat addition can affect IMF deposition. Feeding high-oil corn (1.3\% more total lipid than typical corn) enhanced IMF deposition in predominantly Angus finishing crossbred steers [94].

In addition to FAs, a glycerol "backbone", mainly supplied by glucose, is needed for TG synthesis. Therefore, increased glucose availability is important for providing glycerol for IMF deposition in ruminants [69], similar to monogastric animals such as pigs. Increasing propionate production for glucose synthesis is also important for IMF deposition, especially during the fattening period. For this reason, a large amount of concentrate is fed during the fattening period in Japanese Wagyu and Korean beef cattle [95,96].

High levels of IMF deposition requires excess energy consumption above the maintenance and normal production requirements [69]. Proliferative potential is lower in intramuscular preadipocytes than in subcutaneous preadipocytes [97]. IMF also has lower lipogenic activity than does subcutaneous fat [98]. Our research also showed that IMF had the lowest transcriptional activity for many adipose development and lipid metabolism genes, including adipogenesis, FA transport, lipogenesis, lipolysis, and FA oxidation among several fat depots (abdominal, perirenal, subcutaneous, and intramuscular) of Korean cattle [7]. These results suggest that higher energy levels are required for IMF deposition than for general body fat deposition, including for subcutaneous fat deposition.

TG hydrolysis by lipolysis generates NEFAs and glycerol, and it decreases IMF deposition, as lipolysis is a fat mobilisation pathway. Stress increases circulating concentrations of cortisol, a typical stress marker [99]. Cortisol is also an important regulator of energy metabolism, including the regulation of lipolysis and lipogenesis, and increases plasma NEFA concentrations [100]. Cold stress stimulates lipolysis by increasing the secretion of stress hormones including epinephrine and norepinephrine in humans [101]. Cold stress causes white fat depot lipolysis in rats [102]. In addition, our recent research has shown that transport stress causes temporal increases in circulating cortisol and NEFA concentrations, along with a decrease in circulating TG concentration in pregnant Holstein heifers [103], consistent with transport stress also causing lipolysis. Thus, stressors, such as temperature and transportation, may have a negative effect on IMF deposition through lipolysis in beef cattle. Therefore, fat degradation by lipolysis should be minimized to prevent loss of IMF, and management and transport systems that minimize stress are needed. Fat supplementation for extra energy supply has been recommended during cold or heat stress to prevent fat degradation. Feeding medium-chain TGs, such as coconut oil increased the lipid content in the liver and carcasses of Holstein calves under cold stress [104]. However, some studies have revealed that mild temperature stress can increase body fat deposition and marbling for insulation and other purposes [74,82], as described above. Further study is warranted to clarify how stress intensity affects animal performance and fat deposition.

\section{Fat digestion and absorption}

Many of the FAs generated by digestion in the rumen pass into the small intestine, where they are absorbed into circulation via the lymph and blood. Most ( 90\%) dietary lipids reach the duodenum as NEFAs, unless they are protected [105]. Protected dietary fats are bypassed in the rumen without digestion, and they are digested and absorbed in the small intestine. Manipulating dietary fat digestion and absorption in the small intestine may enhance MS. Emulsifying fat may affect the digestion and absorption of fat. Emulsifier supplementation increased digestion and absorption of a high energy/ fat diet in ruminants [106,107]. The emulsifier PROSOL (sodium stearoyl-2-lactylate) increases IMF deposition and QG in Korean cattle [108]. Bile salts are amphipathic compounds that act as biological detergents, converting dietary fats into mixed micelles of bile salts and TGs [109]. Micelle formation profoundly increases the fraction of lipid molecules accessible to the action of intestinal lipase, aiding fat digestion in the intestine. Bile acid supplementation may enhance fat digestion. Ursodeoxycholic acid, which is a bile acid, is synthesized chemically from cholic acid. Ursodeoxycholic acid supplementation increased IMF and QG in Wagyu heifers [26], demonstrating that bile acid supplementation improves IMF deposition, probably by increasing intestinal fat digestion and absorption by increasing fat emulsification.

\section{Glucose/starch availability and roughage vs concentrate ratios}

Consuming surplus net energy is an important factor for deposition of IMF. Feeding cereal grains is one way to raise net energy supply because energy dense grains can be utilized in the rumen and the small intestine to produce volatile fatty acids and glucose for energy production. Maximum starch utilization can be achieved by optimizing fermentation of starch in the rumen to produce propionate (gluconeogenic precursor) and maximizing starch digestion and absorption in the small intestine. Increasing digestion of rumen-bypassed starch in the small intestine helps increase the glucose supply. A considerable amount of glucose is absorbed from the small intestine when high-starch diets are fed, especially during the beef cattle fattening period. Ørskov [110] reported that up to $42 \%$ of dietary starch may escape ruminal fermentation and reach the small intestine. Harmon and McLeod [111] reported that starch digestion is more efficient in the small intestine than during fermentation in the rumen: the total energetic efficiency of rumen-fermented starch was about $73 \%$ that of small in- 
testine-digested starch.

A meta-analysis of starch digestion in dairy cows revealed that the ruminal digestibility of corn was $57.4 \%$ [112], demonstrating that a substantial portion of corn can be digested in the small intestine. The same report estimated that up to 2 $\mathrm{kg}$ of starch/d can be digested in the small intestine of dairy cows; the average starch digestibility in the small intestine was $60.6 \%$. Therefore, a better method to achieve high digestibility of starch in the small intestine is required to provide high postabsorptive glucose to the host animal. Pethick et al [69] reported that a high level of diet processing can increase the accessibility of dietary starch granules for both rumen and small intestine amylases, resulting in maximum glucose availability to the fattening animal [113]. The decreased flake thickness of steam-flaked sorghum increased starch digestion and liver gluconeogenesis [114]. Grain type and processing affect IMF content [115]: maize is more effective at increasing IMF content than is barley, followed by sorghum. Steam flaking further increases marbling in cases of maize and sorghum, and is more effective for sorghum. Bindon [115] suggested that maize produces increased glucose from digestion in the small intestine and that steam flaking increases digestion in both the rumen and small intestine. Pethick et al [69] suggested that feed that has a high glycemic index to allow rapid glucose absorption and concomitant high insulin levels through either grain feeding instead of grass finishing or grain processing provides increased net energy levels for FA synthesis.

Several studies have reported higher IMF content in high concentrate diets compared with low concentrate diets (reviewed in Wood et al [116]). Yearling Brangus $\times$ Hereford $\times$ Angus steers fed a high grain diet (79\% corn) had more growth performance, greater MS, and higher grade meat than did steers fed a forage diet (winter wheat pasture with sorghumSudan and Bermuda grass pasture) [117]. Increasing the percentage of concentrate ( $60 \%, 75 \%$, and $90 \%$ concentrate) in growing diets increased MS in steers [118]. Pooled results from Angus, Shorthorn, Murray Grey, and Hereford showed that the grain-finishing group had a greater IMF\% than the grass-finishing group [115]. In bulls of two Portuguese breeds (Alentejana and Barrosã), the effects of high (70\% concentrate $30 \%$ maize silage) and low isoenergetic and isonitrogenous concentrates (30\% concentrate $70 \%$ maize silage) on IMF contents were examined in the longissimus lumborum and the semitendinosus muscles [119]. The IMF contents in longissimus lumborum and semitendinosus muscle were higher in highconcentrate-fed than in low-concentrate-fed Barrosã bulls. However, this difference was not observed in Alentejana bulls, indicating a breed difference in IMF content in response to the roughage-to-concentrate ratio. American Wagyu steers fed a high-corn diet had greater fat accumulation than did animals fed a hay-based diet [120]. Similarly, dietary forage level affected MS. Jersey steers fed a low forage diet (6\% Sudan grass,
6\% alfalfa hay and $63.15 \%$ steam-flaked corn, dry matter [DM] basis) in a feedlot finishing diet had greater MS in the strip loin than did animals fed a high forage level diet (12\% Sudan grass, $12 \%$ alfalfa hay and $51.20 \%$ steam-flaked corn) [121]. The effects of roughage/concentrate ratio on body fat deposition and the expression of angiogenic and adipogenic factors in adipose tissue have been examined in fattening Wagyu steers [122]. Steers were fed the same total digestible nutrient (TDN) but different dietary roughage/concentrate ratios (lowconcentrate group: $35 \%$ roughage and $65 \%$ concentrate; highconcentrate group: $10 \%$ roughage and $90 \%$ concentrate). The IMF content in the LM of the high-concentrate group (31.7\% $\pm 5.4 \%)$ was greater than that in the low-concentrate group $(22.9 \% \pm 5.3 \%)$. However, fat weights in the subcutaneous, mesenteric, and intermuscular regions were not different between the groups. The expression of adipogenic factors (CCAAT/enhancer binding protein beta, CCAAT/enhancer binding protein alpha, and PPARG) in the subcutaneous fat and IMF was higher in the high-concentrate group than that in the low-concentrate group, indicating that the dietary roughage/concentrate ratio affects adipogenic gene expression in fat tissues. The same authors suggested that total IMF within the LM in the high-concentrate group might be greater than that in the low-concentrate group by stimulating intramuscular preadipocyte differentiation. Concentrate diets are generally a major glucose source through either production of rumen propionate or glucose absorption from the small intestine from a rumen-bypassed concentrate, as described above, whereas roughage is a major acetate source that results from the rumen fermentation process. Higher IMF deposition with higher concentrate feeding may occur if IMF preferentially uses glucose as a substrate for FA synthesis, while subcutaneous fat uses acetate, as described by Smith and Crouse [88].

\section{Dietary energy and protein levels}

Studies in pigs indicate that a deficiency of essential amino acids such as lysine increases IMF content $[123,124]$, and it has been suggested that an amino acid imbalance relative to energy levels may increase IMF content in cattle (reviewed in Pethick et al [69]). Limited information is available on the effects of the dietary energy-to-protein ratio on IMF content in cattle. Effects of dietary energy (TDN: 70\%, 80\%; DM basis) and protein levels (crude protein [CP]: 11.9\%, 14.3\%; DM basis) on growth performance, carcass characteristics and meat quality were examined in F1 Angus $\times$ Chinese Xiangxi yellow cattle [125]. Steers in the high-energy group had greater LM IMF content than those in the low-energy group, whereas dietary protein levels did not affect IMF content. Podolian bulls fed grazing pasture and fed a high protein (15\% CP, DM basis) supplement had higher IMF content in the LM than did animals grazing pasture and fed a low protein $(12 \% \mathrm{CP})$ supplement [126]. Japanese Black steers fed a 16\% CP diet had 
greater backfat thickness than those fed a 12\% CP diet [127]. However, dietary protein levels do not affect IMF deposition in Angus or Shorthorn steers (reviewed in Bindon [115]). Therefore, current studies are inconsistent in their results and conclusions on the effects of dietary protein levels affect IMF deposition.

\section{Vitamins}

Several vitamins, including vitamins $A, D$, and C, are implicated in regulating IMF deposition.

\section{Vitamin A}

Restricting vitamin A intake increases IMF deposition. Vitamin A (also known as retinol) inhibits adipocyte differentiation [128]. The activity of glycerol-3-phosphate dehydrogenase, a biomarker for adipogenesis, decreases in bovine preadipocytes cultured with retinol [129]. A negative correlation was observed between serum retinol concentrations and carcass MS values in Japanese Black cattle [130,131]. Several studies have shown that restricting vitamin $\mathrm{A}$ in the diet, or low beta-carotene (a precursor of vitamin A) intake, increases body fat, including IMF, deposition. A study of Angus-crossbred steers showed that animals not supplemented with vitamin A had higher MS and QG compared to vitamin A-supplemented animals [132]. The same authors reported that exclusion of a vitamin A supplement induced hyperplasia in IMF, but not in the subcutaneous fat depot. The lack of vitamin A supplementation also increased marbling compared with vitamin A supplementation in a study of Angus crossbred steers [133].

The appropriate age for, and duration of, vitamin A depletion or supplementation have been suggested as important factors that affect MS. Oka et al [134] reported that restricting vitamin A in 15-month-old cattle until the final finishing phase (29 months of age) increased MS, but not in 23-monthold cattle prior to finishing. They suggested that serum vitamin A level affects the LM MS during the early fattening stage and that restricting vitamin A during the later stages of growth affects growth rate. Oka et al [134] recommended selective restriction of dietary vitamin A from 14 to 22 or 25 months of age to improve MS and QG without adverse health effects (blindness, arthritis, and muscular edema), given the effect of vitamin A restriction from 23 months of age in improving MS is minimal. Continuous dietary vitamin A restriction during the late fattening phase is not recommended because prolonged vitamin A restriction may lead to health problems and retard growth rate [130]. Retinoic acid positively regulates growth hormone gene expression [135] and decreases fat deposition and IMF in steers [136]. A continuous supply of normal levels of dietary vitamin A during the entire growth period may also result in poor marbling and QG, even if the growth rate were normal and no health problems occurred. Kawachi [137] described that the number of adipocytes increases in muscle between 13 and 19 months of age, so feeding a vitamin Adeficient diet during this stage may stimulate marbling.

The appropriate concentration range for restriction of vitamin A has been suggested as an important factor for enhancing MS and preventing health-related problems, including the incidence of blindness and muscular edema. Kawachi [137] described that the plasma retinol level in Japanese fattening cattle is about $300 \mu \mathrm{g} / \mathrm{L}(100 \mathrm{IU} / \mathrm{dL})$ and that a vitamin Adeficient diet decreases the plasma concentration to $<90 \mu \mathrm{g} / \mathrm{L}$ (30 IU/dL). Oka [134] recommended that vitamin A-deficient levels not fall below $30 \mathrm{IU} / \mathrm{dL}$ to enhance MS and maintain health.

Alcohol dehydrogenase $1(\mathrm{ADH})$ is the primary enzyme that oxidizes retinol to retinaldehyde [138], and retinaldehyde inhibits adipocyte differentiation [139]. Ward et al [140] examined nutrigenetic interactions between the alcohol dehydrogenase 1C $(A D H 1 C)$ single nucleotide polymorphism ( $A D H 1 C$ c.-64T $>C$ ) and vitamin A levels and the impact on IMF deposition in Angus-cross steers. A significant interaction was detected between $A D H 1 C$ c.-64T $>$ C genotype and vitamin A supplementation for IMF content in the LM. The cattle with a TT genotype (approximately 6.15\%) that were not supplemented with vitamin A had 22.9\% greater IMF compared with those with the CC genotype (approximately 4.95\%). Vitamin A-unsupplemented TT steers (approximately 6.15\%) had $24.4 \%$ greater IMF content compared with supplemented TT steers (approximately 4.9\%). They concluded that the TT genotype of $A D H 1 C$ c. $-64 \mathrm{~T}>\mathrm{C}$ is related to greater IMF than the $\mathrm{CC}$ genotype when vitamin $\mathrm{A}$ is restricted, and $\mathrm{ADH} 1 \mathrm{C}$ c. $-64 \mathrm{~T}>\mathrm{C}$ could be a genetic marker for enhancing marbling in feedlot steers.

\section{Vitamin D}

Vitamin $\mathrm{D}$ also inhibits adipogenesis in vitro. 1,25-Dihydroxyvitamin $\mathrm{D}_{3}$ (active form of vitamin $\mathrm{D}$ ) inhibits preadipocyte differentiation [141] and suppresses adipogenic PPARG gene expression in 3T3 L1 cells [142]. One study reported that 1,25-dihydroxyvitamin $\mathrm{D}_{3}$ inhibited lipid accumulation by inhibiting key adipogenic factors such as PPARG [143]. Wang et al [144] suggested that the vitamin D receptor (VDR) competes with PPARG for binding to the retinoid X receptor (RXR). Higher VDR/RXR binding may decrease formation of the PPARG/RXR heterodimer, thus inhibiting adipogenesis (Figure 4). Few in vivo studies have been performed on the effect of vitamin $\mathrm{D}$ on beef marbling. While vitamin A restriction improves marbling, but vitamin $\mathrm{D}$ restriction did not significantly affect marbling in Angus crossbred steers [133]. Further study is needed to clarify the effects of dietary vitamin D on MS and QG in beef cattle.

Smith et al [145] suggested a possible connection between 1,25-dihydroxyvitamin $\mathrm{D}_{3}$ and calcium homeostasis in the regulation of marbling. The increase in blood 1,25-dihydroxy- 


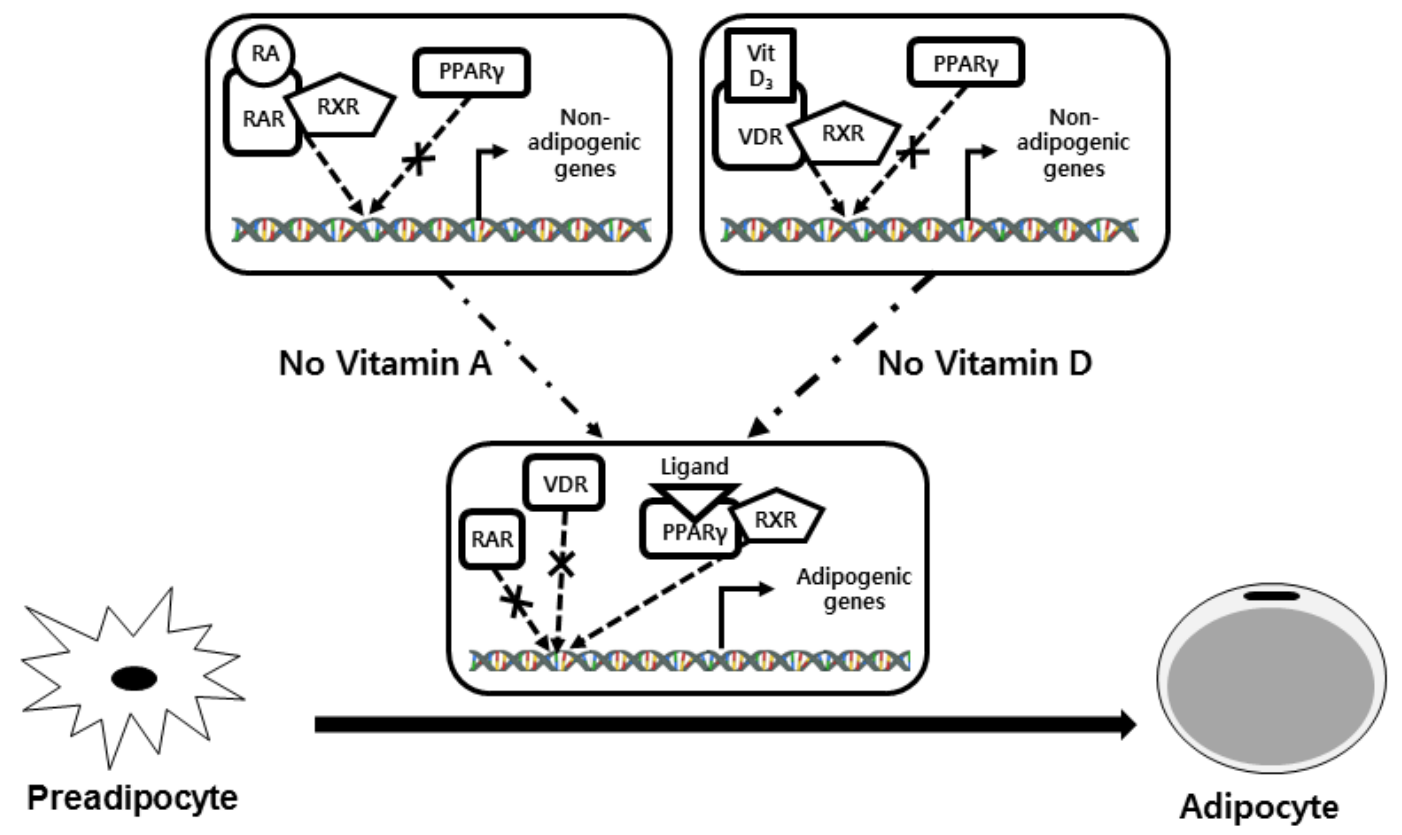

Figure 4. Transcriptional regulation of adipogenesis gene expression by retinoic acid (RA) and vitamin D. RA (an active form of vitamin A) binds to the retinoic acid receptor (RAR), and vitamin $D_{3}\left(\right.$ Vit $\left.D_{3}\right)$ binds to the vitamin $D$ receptor (VDR). The RA and vitamin $D_{3}$ may inhibit adipogenic gene expression by competing for retinoid $X$ receptor (RXR) binding with peroxisome proliferator-activated receptor $\gamma$ (PPAR $\gamma$ ), which is a key transcription factor for adipogenesis. Modified from Pyatt and Berger [163].

vitamin $\mathrm{D}_{3}$ levels in response to decreased calcium intake may downregulate preadipocyte differentiation, thus decreasing beef marbling.

\section{Vitamin C}

Vitamin C can be synthesized from glucose in the liver of many mammalian species other than guinea pigs, humans, and other primates [146]. Thus, the dietary vitamin C requirement for beef cattle is not specified in the NRC [146]. Vitamin $\mathrm{C}$ or L-ascorbic acid has several roles including in oxidationreduction reactions and collagen synthesis [147]. In addition, vitamin $\mathrm{C}$ may help to regulate adipogenesis. Vitamin $\mathrm{C}$ increased preadipocyte growth of 3T3 L1 cells [148] and also had a positive effect on differentiation of sheep preadipocytes in primary culture [149]. A rumen-protected form of vitamin $\mathrm{C}$ is preferred as a dietary supplement because vitamin $\mathrm{C}$ is most likely degraded in the rumen [146]. In vivo studies showed increased marbling in response to dietary vitamin $\mathrm{C}$ supplementation in beef cattle; dietary supplementation of rumenprotected 1-ascorbic acid-2-phosphate during the final fattening period increased both MS and fat content in carcasses of Japanese Black cattle [150]. Supplementing rumen-protected vitamin $\mathrm{C}$ in a high sulfur diet increased the MS and the percentage of Choice grade beef in Angus cross steers [151]. Further study is necessary to clarify the effects of dietary vitamin C on MS and QG in other breeds of beef cattle.

\section{Fetal nutritional programming}

Fetal programming or prenatal programing is the concept that mammalian embryonic and fetal development are linked to environmental changes, thus affecting the entire life [152]. The development of adipose tissue coincides with myogenesis during a particular time in fetal development [18]. The gestation period is very important because it determines the fate of progenitor cells that will become muscle cells, fibroblasts, or adipocytes [16]. Nutritional manipulation of the fetus during gestation may affect animal performance and modify the quality and quantity of livestock products. Therefore, fetal nutritional programming via nutrition of dams during gestation may be one way to increase marbling in offspring later in life. Several studies have shown that fetal nutritional programming affects growth and/or beef quality, including marbling. For example, the effects of a $30 \%$ nutrient restriction in cows at early to mid-gestation on offspring (steers and heifers) growth and adiposity were tested in Angus $\times$ Gelbvieh [153]. Adipocyte diameter in subcutaneous, mesenteric, and omental fat was larger in offspring of dams nutritionally restricted than in animals from dams with normal dietary intake (100\% of NRC recommendations), but marbling data were not reported. In their study, YG was reduced, and HCW tended to be reduced in offspring of dams nutritionally restricted. In addition, nutritional restriction during early and mid gestation reduced ovarian characteristics (wet ovary weight, luteal tissue weight) of heifers, indicating negative effects of fetal programming on productive efficiency of replacement heifers. Negative maternal energy status at mid-gestation ( $80 \%$ of the energy requirements for maintenance of body weight) did not affect MS, intramuscular fat percentage, and HCW, but increased the 
ratio of MS to 12th rib fat thickness and the ratio of percent intramuscular fat to 12th rib fat thickness in offspring compared with positive energy status [154]. This study indicates little or no effect of reduced maternal energy status during midgestation on offspring IMF deposition and muscle mass. Improving the nutritional condition of cows during pregnancy affects growth, fat deposition, and beef quality in steers; steers from cows grazing with better pasture (ThinopyrumElymus-Psathrystachus, CP $11.1 \%$ to $6.0 \%$ ) during mid- to late gestation had greater live body weight at slaughter, HCW, and tenderness, and had an increased tendency for IMF deposition compared with offspring of cows grazing on native range (Bouteloua-Hesperostipa-Pascopyron, CP 6.5\% to 5.4\%) [155]. Effects of nutritional restriction from early gestation to parturition and/or throughout lactation on offspring growth and production characteristics to $30 \mathrm{mo}$ of age and health and reproductive performance of cows were studied in large maternal grazing systems with offspring of Hereford cows mated to Piedmontese or Wagyu sires [33]. Fetal programming of nutritional restriction with pasture-based systems retarded offspring growth performance (body weight, feed intake, carcass weight) and production parameters including muscle weight, meat yield, and fat and bone weight at any given age. However, the fetal programming did not significantly affect beef quality characteristics at $30 \mathrm{mo}$ of age. In addition, authors emphasize importance of survival and health of cows and calves and of subsequent reproductive performance of cows for relative contribution of fetal programming to the profitability of beef production systems when developmental programming is applied [33].

Radunz et al [156] tested the effects of three maternal lategestational dietary energy sources (grass hay, corn, and dried corn distillers grains with solubles) on progeny postnatal growth and beef MS in an Angus cross-breed. The dams were limited in their feed to maintain similar energy intake among the groups. In the study, steers from dams fed a corn-based diet during late gestation had a lower MS compared with progeny from dams fed diets low in starch (grass hay or dried corn distillers grains with solubles). The authors suggested that the prepartum maternal dietary energy source during late gestation can alter the development of fetal adipose tissue, affecting IMF deposition in progeny. However, studies during postnatal periods (after weaning or finishing period) show that feeding a high starch diet along with early weaning in steers generally increased marbling, as described above $[51,53,157]$. Thus, the dietary energy source may differentially influence marbling and IMF deposition, depending on the feeding period.

Overall, nutritional manipulation during the early, mid-, or late gestation period may affects adiposity or marbling of beef, but these effects are generally small and often masked by postnatal nutritional status, as mentioned by Bell and Greenwood [158]. Further study is warranted to understand what mechanisms affect the adipogenic potential by nutritional modulation during the fetal period at specific gestation stages, thereafter affecting marbling and IMF deposition at the progeny slaughter stage. Proper nutritional levels and proper selection of the types of energy sources for dams during each period of gestation stages may improve future production efficiency of progeny. Some of the results presented above suggest restricted nutrition at certain stages of pregnancy has more favourable outcomes. Bell and Greenwood [158] also suggest that effects of fetal programming during early-mid-gestation on postnatal growth or composition are generally minor. One of the mechanisms responsible for the effect of fetal nutritional programming on growth and adiposity of progeny is epigenetic modification (DNA methylation, histone modification, and microRNA) of gene expression during early development and permanent changes in offspring phenotypes in later life. Epigenetic modifications have been suggested to occur during development (fetal programming), growth, and fat deposition in cattle $[13,18,159]$. Our previous study showed the possible involvement of DNA methylation in regulating tissue-specific expression of $P P A R G$ gene in IMF and muscle of beef cattle [6].

\section{Stage-specific feeding systems}

A significant proportion of consumers in Korea, Japan, and the USA prefer highly marbled beef to minimally marbled beef. Thus, Korean and Japanese beef production systems have focused on production of highly marbled beef to satisfy their customers and to protect their beef industry against imported beef that has relatively low MS. As described above, several nutritional factors affect IMF deposition, and these factors must be considered to prepare a proper diet to improve marbling at the proper time in the life cycle. Japan and Korea have developed stage-specific feeding systems to produce highly marbled beef. The feeding system for highly marbled beef from Japanese Black cattle has been described previously in a review by Gotoh et al [95]. Briefly, Japanese Black cattle are generally fed a high concentrate diet from 11 to 30 months of age to induce deposition of IMF. The concentrate constitutes $36.8 \%$ to $86.4 \%$ of feed from 11 to 18 months of age. During the final stage, from 18 months to slaughter (28 to 30 months of age), the concentrate is $84.2 \%$ to $86.4 \%$ of feed, and the rest is roughage (rice straw). In addition, Japanese farmers generally restrict vitamin A levels in the diet during the mid-fattening stage to produce highly marbled Japanese Black cattle beef.

Similarly, a growth stage-specific feeding system has generally been applied to Korean cattle to produce highly marbled beef. The Korean Feeding Standard for Hanwoo [160] describes how to feed Korean cattle at each stage (growth, early fattening, and late fattening stages). The feeding strategy for highly marbled Korean cattle beef has been also described by Jo et al [96]. Briefly, high-quality forage is fed ad libitum to 
develop the rumen during the growing stage (7 to 12 months of age), and the concentrate (CP $15 \%$ to $16 \%$, TDN $69 \%$ to $70 \%$ ) is restricted to $1.5 \%$ to $1.6 \%$ of body weight at this time. The fattening period can be divided into early and late periods, during which the concentrate is mainly fed with a small portion of roughage. Feed comprising about $80 \%$ concentrate ( $1.6 \%$ to $1.9 \%$ of body weight; CP $12 \%$ to $13 \%$, TDN $72 \%$ to $73 \%$ ) is provided during the early fattening stage (13 to 21 months of age). During the late fattening phase, from 22 months to slaughter age (28 to 31 months of age), about $90 \%$ concentrate (CP $11 \%$ to $12 \%$, TDN $73 \%$ to $74 \%$ ) is fed, and roughage (rice straw and rye grass) is about $10 \%$ of the diet. Korean farmers often feed a total mixed ration during the growing and early finishing stages instead of feeding concentrate and roughage separately. The mixed ration is made by using agricultural by-products (soybean curd cake and pomace of citrus, apple, and carrot) [96].

\section{CONCLUSION}

In this article, we reviewed several factors (genetic, management, and nutritional factors) affecting IMF deposition in cattle (Table 2). IMF deposition can positively affect beef taste including tenderness and flavor, favoring highly marbled beef. The current stage-specific feeding program for producing Korean cattle with highly marbled beef relies heavily on feeding a concentrate diet during the fattening period. This program has several limitations: the high proportion of concentrate in the diet and long fattening period ( $>30$ months, especially in
Korean cattle and Japanese Black cattle) may increase feed costs. Excess energy supplied to mature animals during the late fattening period may significantly decrease feed efficiency. This may decrease digestibility of feed, increase animal feed waste, and eventually raise issues of animal industry sustainability. Current methods to increase IMF deposition are generally limited to increasing overall body fat deposition, including inedible fat. Further studies are needed to develop methods for producing highly marbled beef without increasing overall body fat deposition, including internal (abdominal, perirenal, mesenteric) and external (subcutaneous) inedible fat. In addition, high IMF deposition may negatively affect YG (or retail beef yield). Some sires may have high breeding value for both IMF and YG, and selection of such sires is likely to be beneficial for increasing IMF deposition without decreasing YG.

Applying a single factor (e.g., nutritional or genetic) may not be adequate to increase IMF deposition. Development of new fusion technologies (e.g., nutrigenomics) with genetic, epigenetic, and nutritional factors may be more efficient to optimize IMF deposition and improve feed efficiency. Nutritional programming during the fetal and neonatal periods has been suggested as a promising method to manipulate IMF deposition. Further studies are warranted to test the feasibility of early nutritional programming for regulating IMF deposition in cattle.

There has been increasing concerns by consumers about the negative impact of extremely highly marbled beef on human health, such as cardiovascular diseases and arteriosclerosis.

Table 2. Summary of factors affecting intramuscular fat (IMF) deposition in beef cattle

\begin{tabular}{ll}
\hline Factors & Description summary \\
\hline $\begin{array}{l}\text { Genetic factors } \\
\text { Breed differences }\end{array}$ & IMF content varies with cattle breed \\
Sex & Sex affects IMF deposition \\
Management factors & Heritabilities of marbling in Korean cattle and Japanese Wagyu are relatively high \\
Weaning age & \\
Castration & Early weaning age generally increases IMF deposition \\
Slaughter age & Castration generally increases IMF deposition \\
Slaughter weight & IMF content increases with increasing age in most cattle breeds \\
Environments & IMF content increases with increasing slaughter weight in several cattle breeds \\
Nutritional factors & Environmental conditions, such as ambient temperature, can affect IMF deposition \\
Fat metabolism & \\
Fat digestion and absorption & Triglyceride synthesis is a key factor for IMF deposition, whereas the TG hydrolysis decreases IMF deposition \\
Glucose/starch availability & Manipulation of dietary fat digestion and absorption in small intestine may enhance IMF deposition \\
& Maximum starch utilization is important for IMF deposition and can be achieved by both optimum rumen fermentation of \\
Roughage vs concentrate ratio & Starch and by maximum starch digestion and absorption in the small intestine \\
Vitamin A & IMF content increases with increasing percentage of concentrate in the diet \\
Vitamin D & Vitamin A restriction generally increases IMF deposition \\
Vitamin C & Vitamin D generally inhibits adipogenesis in in vitro studies \\
Fetal nutritional programming & Vitamin C has a positive effect on differentiation of sheep preadipocytes \\
Stage-specific feeding systems & Fetal nutritional manipulation at early, mid-, or late gestation period can affect adiposity of offspring in later life \\
\hline
\end{tabular}


Additional studies are warranted to produce beef with appropriate levels of IMF deposition to satisfy beef quality and taste, support human health, and sustain the animal industry, depending on the situation of each country.

\section{CONFLICT OF INTEREST}

We certify that there is no conflict of interest with any financial organization regarding the material discussed in the manuscript.

\section{ACKNOWLEDGMENTS}

This study was supported by Korea Institute of Planning and Evaluation for Technology in Food, Agriculture, Forestry and Fisheries (IPET) through Agri-Bio industry Technology Development Program, funded by Ministry of Agriculture, Food and Rural Affairs (MAFRA) (118053-03-1-SB010), Republic of Korea and by the National Research Foundation of Korea (NRF) grant funded by the Korea government (MSIT) (2017 R1A2B4003207), Republic of Korea.

\section{REFERENCES}

1. Wheeler TL, Cundiff LV, Koch RM. Effect of marbling degree on beef palatability in Bos taurus and Bos indicus cattle. J Anim Sci 1994;72:3145-51.

2. Piao MY, Baik M. Seasonal variation in carcass characteristics of Korean cattle steers. Asian-Australas J Anim Sci 2015;28: 442-50.

3. Hunt MR, Garmyn AJ, O'Quinn TG, et al. Consumer assessment of beef palatability from four beef muscles from USDA Choice and Select graded carcasses. Meat Sci 2014;98:1-8.

4. Moody WG, Cassens RG. A quantitative and morphological study of bovine longissimus fat cells. J Food Sci 1968;33:47-52.

5. Smith SB, Lunt DK, Zembayashi M. Intramuscular fat deposition. The physiological process and the potential for its manipulation. In: Proceeding of the Plains Nutrition Council 2000; 2000 Apr 13-14: San Antonio, TX, USA: Texas A\&M Research and Extension Center; 2000. pp. 1-12.

6. Baik M, Vu TTT, Piao MY, Kang HJ. Association of DNA methylation levels with tissue-specific expression of adipogenic and lipogenic genes in longissimus dorsi muscle of Korean cattle. Asian-Australas J Anim Sci 2014;27:1493-8.

7. Baik M, Jeong JY, Vu TTT, Piao MY, Kang HJ. Effects of castration on the adiposity and expression of lipid metabolism genes in various fat depots of Korean cattle. Livest Sci 2014;168:16876.

8. Baik M, Nguyen TH, Jeong JY, Piao MY, Kang HJ. Effects of castration on expression of lipid metabolism genes in the liver of Korean cattle. Asian-Australas J Anim Sci 2015;28:127-34.

9. Bong JJ, Jeong JY, Rajasekar P, et al. Differential expression of genes associated with lipid metabolism in longissimus dorsi of Korean bulls and steers. Meat Sci 2012;91:284-93.

10. Jeong J, Kwon EG, Im SK, Seo KS, Baik M. Expression of fat deposition and fat removal genes is associated with intramuscular fat content in longissimus dorsi muscle of Korean cattle steers. J Anim Sci 2012;90:2044-53.

11. Jeong J, Kim JS, Nguyen TH, Lee HJ, Baik M. Wnt/beta-catenin signaling and adipogenic genes are associated with intramuscular fat content in the longissimus dorsi muscle of Korean cattle. Anim Genet 2013;44:627-35.

12. Jeong J, Bong JJ, Kim GD, et al. Transcriptome changes favoring intramuscular fat deposition in the longissimus muscle following castration of bulls. J Anim Sci 2013;91:4692-704.

13. Baik M, Kang HJ, Park SJ, et al. Triennial growth and development ymposium: molecular mechanisms related to bovine intramuscular fat deposition in the longissimus muscle. J Anim Sci 2017;95:2284-303.

14. Hood RL, Allen CE. Cellularity of bovine adipose tissue. J Lipid Res 1973;14:605-10.

15. Owens FN, Dubeski P, Hanson CF. Factors that alter the growth and development of ruminants. J Anim Sci 1993;71:3138-50.

16. Du M, Huang Y, Das AK, et al. Meat science and muscle biology symposium: manipulating mesenchymal progenitor cell differentiation to optimize performance and carcass value of beef cattle. J Anim Sci 2013;91:1419-27.

17. Du M, Tong J, Zhao J, et al. Fetal programming of skeletal muscle development in ruminant animals. J Anim Sci 2010;88:E5160 .

18. Du M, Wang B, Fu X, Yang Q, Zhu MJ. Fetal praogramming in meat production. Meat Sci 2015;109:40-7.

19. Hausman GJ, Dodson MV, Ajuwon K, et al. Board-invited review: the biology and regulation of preadipocytes and adipocytes in meat animals. J Anim Sci 2009;87:1218-46.

20. Bonnet M, Cassar-Malek I, Chilliard Y, Picard B. Ontogenesis of muscle and adipose tissues and their interactions in ruminants and other species. Animal 2010;4:1093-109.

21. Uezumi A, Ito T, Morikawa D, et al. Fibrosis and adipogenesis originate from a common mesenchymal progenitor in skeletal muscle. J Cell Sci 2011;124:3654-64.

22. Huang Y, Das AK, Yang QY, Zhu MJ, Du M. Zfp423 promotes adipogenic differentiation of bovine stromal vascular cells. PLoS One 2012;7:e47496.

23. Harper GS, Pethick DW. How might marbling begin? Aust J Exp Agric 2004;44:653-62.

24. Albrecht E, Teuscher F, Ender K, Wegner J. Growth- and breedrelated changes of marbling characteristics in cattle. J Anim Sci 2006;84:1067-75.

25. Albrecht E, Gotoh T, Ebara F, et al. Cellular conditions for intramuscular fat deposition in Japanese Black and Holstein steers. Meat Sci 2011;89:13-20.

26. Irie M, Kouda M, Matono H. Effect of ursodeoxycholic acid supplementation on growth, carcass characteristics, and meat 
quality of Wagyu heifers (Japanese Black cattle). J Anim Sci 2011;89:4221-6.

27. Cho SH, Kang GH, Seong PN, et al. Effect of slaughter age on the antioxidant enzyme activity, color, and oxidative stability of Korean Hanwoo (Bos taurus coreanae) cow beef. Meat Sci 2015;108:44-9.

28. Choi CB, Jung KK, Chung KY, et al. Administration of zilpaterol hydrochloride alters feedlot performance, carcass characteristics, muscle, and fat profiling in finishing Hanwoo steers. Livest Sci 2013;157:435-41.

29. Jung S, Nam KC, Lee KH, et al. Meat quality traits of longissimus dorsi muscle from carcasses of Hanwoo steers at different yield grades. Korean J Food Sci Anim Resour 2013;33:305-16.

30. Greenwood PL, Siddell JP, Walmsley BJ, et al. Postweaning substitution of grazed forage with a high-energy concentrate has variable long-term effects on subcutaneous fat and marbling in Bos taurus genotypes. J Anim Sci 2015;93:4132-43.

31. Krone KG, Ward AK, Madder KM, et al. Interaction of vitamin A supplementation level with $\mathrm{ADH1C}$ genotype on intramuscular fat in beef steers. Animal 2016;10:403-9.

32. Dinh TT, Blanton JR Jr, Riley DG, et al. Intramuscular fat and fatty acid composition of longissimus muscle from divergent pure breeds of cattle. J Anim Sci 2010;88:756-66.

33. Robinson DL, Café LM, Greenwood PL. Developmental programming in cattle: Consequences for growth, efficiency, carcass, muscle, and beef quality characteristics. J Anim Sci 2013;91:1428-42.

34. Lapitan RM, Del Barrio AN, Katsube O, et al. Comparison of carcass and meat characteristics of Brahman grade cattle (Bos indicus) and crossbred water buffalo (Bubalus bubalis). Anim Sci J 2007;78:596-604.

35. Lapitan RM, Del Barrio AN, Katsube O, et al. Comparison of carcass and meat characteristics of Brahman grade cattle (Bos indicus) and crossbred water buffalo (Bubalus bubalis) fed on high roughage diet. Anim Sci J 2008;79:210-7.

36. Miguel JA, Ciria J, Asenjo B, et al. Chemical composition of meat in castrated male Brahman cattle in Venezuela. J Life Sci 2011:5;562-8.

37. Burrow HM, Moore SS, Johnston DJ, Barendse W, Bindon BM. Quantitative and molecular genetic influences on properties of beef: a review. Aust J Exp Agric 2001;41:893-919.

38. Marti S, Realini CE, Bach A, Pérez-Juan M, Devant M. Effect of castration and slaughter age on performance, carcass, and meat quality traits of Holstein calves fed a high-concentrate diet. J Anim Sci 2013;91:1129-40.

39. Park GB, Moon SS, Ko YD, et al. Influence of slaughter weight and sex on yield and quality grades of Hanwoo (Korean native cattle) carcasses. J Anim Sci 2002;80:129-36.

40. Seideman SC, Cross HR, Oltjen RR, Schanbacher BD. Utilization of the intact male for red meat production: a review. J Anim Sci 1982;55:826-40.

41. Utrera RA, Van Vleck LD. Heritability estimates for carcass traits of cattle: a review. Genet Mol Res 2004;3:380-94.

42. Yoon HB, Seo KS, Kim SD, et al. Estimation of genetic parameters for direct genetic effect for carcass traits of Hanwoo (Korean Brown cattle) steers. In: Proceedings of the 7th World Congress on Genetics Applied to Livestock Production 2002; 2002 Aug 19-23: Montpellier, France. Session 02. Breeding ruminants for meat production. Communication No. 02-89.

43. Park B, Choi T, Kim S, Oh SH. National genetic evaluation (system) of Hanwoo (Korean naitve cattle). Asian-Australas J Anim Sci 2013;26:151-6.

44. Hirooka H, Groen AF, Matsumoto M. Genetic parameters for growth and carcass traits in Japanese brown cattle estimated from field records. J Anim Sci 1996;74:2112-6.

45. Nogi T, Honda T, Mukai F, Okagaki T, Oyama K. Heritabilities and genetic correlations of fatty acid compositions in longissimus muscle lipid with carcass traits in Japanese black cattle. J Anim Sci 2011;89:615-21.

46. Oyama K. Genetic variability of Wagyu cattle estimated by statistical approaches. Anim Sci J 2011;82:367-73.

47. MacNeil MD, Nkrumah JD, Woodward BW, Northcutt SL. Genetic evaluation of Angus cattle for carcass marbling using ultrasound and genomic indicators. J Anim Sci 2010;88:51722 .

48. Riley DG, Chase CC, Hammond AC, et al. Estimated genetic parameters for carcass traits of Brahman cattle. J Anim Sci 2002; 80:955-62.

49. Smith T, Domingue JD, Paschal JC, et al. Genetic parameters for growth and carcass traits of Brahman steers12. J Anim Sci 2007;85:1377-84.

50. Black DN, Neville BW, Crosswhite MR, Dahlen CR. Evaluation of implant strategies in Angus-sired steers with high or low genetic potential for marbling and gain. J Anim Sci 2015;93: 5411-8.

51. Meyer DL, Kerley MS, Walker EL, et al. Growth rate, body composition, and meat tenderness in early vs. traditionally weaned beef calves. J Anim Sci 2005;83:2752-61.

52. Wolcott ML, Graser HU, Johnston DJ. Effects of early weaning on growth, feed efficiency and carcass traits in Shorthorn cattle. Anim Prod Sci 2010;50:315-21.

53. Wertz AE, Berger LL, Walker PM, et al. Early-weaning and postweaning nutritional management affect feedlot performance, carcass merit, and the relationship of 12th-rib fat, marbling score, and feed efficiency among Angus and Wagyu heifers. J Anim Sci 2002;80:28-37.

54. Scheffler JM, McCann MA, Greiner SP, et al. Early metabolic imprinting events increase marbling scores in fed cattle. J Anim Sci 2014;92:320-4.

55. Moisa SJ, Shike DW, Faulkner DB, et al. Central role of the PPARgamma gene network in coordinating beef cattle intramuscular adipogenesis in response to weaning age and nutrition. Gene Regul Syst Bio 2014;8:17-32.

56. Graugnard DE, Berger LL, Faulkner DB, Loor JJ. High-starch 
diets induce precocious adipogenic gene network up-regulation in longissimus lumborum of early-weaned Angus cattle. Br J Nutr 2010;103:953-63.

57. Smith SB, Johnson BJ. Marbling: management of cattle to maximize the deposition of intramuscular adipose tissue. Centennial, CO, USA: National Cattlemen's Beef Association; 2014.

58. Reddy KE, Jeong J, Lee SD, et al. Effect of different early weaning regimens for calves on adipogenic gene expression in Hanwoo loin at the fattening stage. Livest Sci 2017;195:87-98.

59. eKAPEpia. Grade evaluation of cattle [Internet]. Korea Institute for Animal Products Quality Evaluation; c2017 [cited 2017 Dec 27]. Available from: http://www.ekapepia.com/user/ distribution/distDetail.do?nd1906

60. Jones SDM, Tong AKW, Talbot S. A survey of marbling fat in Canadian beef carcasses. Can J Anim Sci 1991;71:987-91.

61. Gotoh T, Joo ST. Characteristics and health benefit of highly marbled Wagyu and Hanwoo beef. Korean J Food Sci Anim Resour 2016;36:709-18.

62. Choi BH, Ahn BJ, Kook K, et al. Effects of feeding patterns and sexes on growth rate, carcass trait and grade in Korean native cattle. Asian-Australas J Anim Sci 2002;15:838-43.

63. Purchas RW, Burnham DL, Morris ST. Effects of growth potential and growth path on tenderness of beef longissimus muscle from bulls and steers. J Anim Sci 2002;80:3211-21.

64. Rodriguez J, Unruh J, Villarreal M, et al. Carcass and meat quality characteristics of Brahman cross bulls and steers finished on tropical pastures in Costa Rica. Meat Sci 2014;96:1340-4.

65. Okumura T, Saito K, Sowa T, et al. Changes in beef sensory traits as somatic-cell-cloned Japanese black steers increased in age from 20 to 30 months. Meat Sci 2012;90:159-63.

66. Zembayashi M, Nishimura K, Lunt DK, Smith SB. Effect of breed type and sex on the fatty acid composition of subcutaneous and intramuscular lipids of finishing steers and heifers. J Anim Sci 1995;73:3325-32.

67. Kirkland RM, Patterson DC, Keady TW, Moss BW, Steen RW. Beef production potential of Norwegian Red and HolsteinFriesian bulls slaughtered at two ages. Animal 2007;1:1506-14.

68. Lee S-C, Choi H-H, Shin J-S, et al. Carcass characteristics and profitability analysis based on slaughter age of Hanwoo steers. J Anim Sci Technol 2013;55:315-23.

69. Pethick DW, Harper GS, Oddy VH. Growth, development and nutritional manipulation of marbling in cattle: a review. Aust J Exp Agric 2004;44:705-15.

70. Agastin A, Naves M, Farant A, et al. Effects of feeding system and slaughter age on the growth and carcass characteristics of tropical-breed steers. J Anim Sci 2013;91:3997-4006.

71. Lorenzen CL, Hale DS, Griffin DB, et al. National Beef Quality Audit: survey of producer-related defects and carcass quality and quantity attributes. J Anim Sci 1993;71:1495-502.

72. Bruns KW, Pritchard RH, Boggs DL. The relationships among body weight, body composition, and intramuscular fat content in steers. J Anim Sci 2004;82:1315-22.
73. Kern SA, Pritchard RH, Blair AD, Scramlin SM, Underwood $\mathrm{KR}$. The influence of growth stage on carcass composition and factors associated with marbling development in beef cattle. J Anim Sci 2014;92:5275-84.

74. Mader TL, Fell LR, McPhee MJ. Behavior response of nonBrahman cattle to shade in commercial feedlots. In: Proceedings of the 5th International Livestock Environment Symposium 1997; 1997: Bloomington, MN, USA. St. Joseph, MI, USA: American Society of Agriculture Biology Engineers; 1997. pp. 795-802.

75. Ames DR, Brink DR, Willms CL. Adjusting protein in feedlot diets during thermal stress. J Anim Sci 1980;50:1-6.

76. Young BA. Cold stress as it affects animal production. J Anim Sci 1981;52:154-63.

77. Birkelo CP, Johnson DE, Phetteplace HP. Maintenance requirements of beef cattle as affected by season on different planes of nutrition. J Anim Sci 1991;69:1214-22.

78. Kang HJ, Lee IK, Piao MY, et al. Effects of ambient temperature on growth performance, blood metabolites, and immune cell populations in Korean cattle steers. Asian-Australas J Anim Sci 2016;29:436-43.

79. Hahn GL. Environmental influences on feed intake and performance of feedlot cattle. In: Owens FN, editor. Proc. Symp. Intake by Feedlot Cattle. Stillwater OK, USA: Oklahoma State University; 1995. pp. 207-25.

80. Yadav B, Pandey V, Yadav S, et al. Effect of misting and wallowing cooling systems on milk yield, blood and physiological variables during heat stress in lactating Murrah buffalo. J Anim Sci Technol 2016;58:2.

81. Young BA. Ruminant cold stress: effect on production. Can J Anim Sci 1983;57:1601-7.

82. Mader TL, Davis MS. Effect of management strategies on reducing heat stress of feedlot cattle: feed and water intake. J Anim Sci 2004;82:3077-87.

83. Kang HJ, Piao MY, Lee IK, et al. Effects of ambient temperature and dietary glycerol addition on growth performance, blood parameters and immune cell populations of Korean cattle steers. Asian-Australas J Anim Sci 2017;30:505-13.

84. Bauman DE, Davis CL. Regulation of lipid metabolism. Digestion and metabolism in the ruminant. In: Proceedings of the 4th International Symposium on Ruminant Physiology; 1975; University of New England Publishing Unit, Armidale, NSW, Australia.

85. Hanson RW, Ballard FJ. The relative significance of acetate and glucose as precursors for lipid synthesis in liver and adipose tissue from ruminants. Biochem J 1967;105:529-36.

86. Nafikov RA, Beitz DC. Carbohydrate and lipid metabolism in farm animals. J Nutr 2007;137:702-5.

87. Ballard FJ, Hanson RW, Kronfeld DS. Gluconeogenesis and lipogenesis in tissue from ruminant and nonruminant animals. Fed Proc 1969;28:218-31.

88. Smith SB, Crouse JD. Relative contributions of acetate, lactate 
and glucose to lipogenesis in bovine intramuscular and subcutaneous adipose tissue. J Nutr 1984;114:792-800.

89. Smith SB, Prior RL, Koong LJ, Mersmann HJ. Nitrogen and lipid metabolism in heifers fed at increasing levels of intake. J Amin Sci 1992;70:152-60.

90. Hocquette JF, Gondret F, Baéza E, et al. Intramuscular fat content in meat-producing animals: development, genetic and nutritional control, and identification of putative markers. Animal 2010;4:303-19.

91. Rhoades RD, Sawyer JE, Chung KY, et al. Effect of dietary energy source on in vitro substrate utilization and insulin sensitivity of muscle and adipose tissues of Angus and Wagyu steers. J Anim Sci 2007;85:1719-26.

92. Laplaud PM, Bauchart D, Durand D, Chapman MJ. Lipoproteins and apolipoproteins in intestinal lymph of the preruminant calf, Bos spp., at peak lipid absorption. J Lipid Res 1990;31: 1781-92.

93. Pethick DW, Harper GS, Dunshea FR. Fat metabolism and turnover. In: Dijkstra J, Forbes JM, editors. Quantitative aspects of ruminant digestion and metabolism. Oxford, UK: CAB International; 1993. pp. 345-71.

94. Andrae JG, Duckett SK, Hunt CW, Pritchard GT, Owens FN. Effects of feeding high-oil corn to beef steers on carcass characteristics and meat quality. J Anim Sci 2001;79:582-8.

95. Gotoh T, Takahashi H, Nishimura T, Kuchida K, Mannen H. Meat producded by Japanese Black cattle and Wagyu. Anim Front 2014;4:46-54.

96. Jo C, Cho SH, Chang J, Nam KC. Keys to production and processing of Hanwoo beef: A perspective of tradition and science. Anim Front 2012;2:32-8.

97. Wan R, Du J, Ren L, Meng Q. Selective adipogenic effects of propionate on bovine intramuscular and subcutaneous preadipocytes. Meat Sci 2009;82:372-8.

98. Bonnet M, Faulconnier Y, Leroux C, et al. Glucose-6-phosphate dehydrogenase and leptin are related to marbling differences among Limousin and Angus or Japanese Black Angus steers. J Anim Sci 2007;85:2882-94.

99. Abelson JL, Khan S, Liberzon I, Young EA. HPA axis activity in patients with panic disorder: review and synthesis of four studies. Depress Anxiety 2007;24:66-76.

100. Parker KL, Rainey WE. The adrenal gland. In: Griffin JE, Ojeda SR, editors. Textbook of endocrine physiology.5th ed. New York, USA: Oxford University Press; 2004. pp. 319-48.

101. Pääkkönen T, Leppäluoto J. Cold exposure and hormonal secretion: a review. Int J Circumpolar Health 2002;61:265-76.

102. Akana SF, Strack AM, Hanson ES, et al. Interactions among chronic cold, corticosterone and puberty on energy intake and deposition. Stress 1999;3:131-46.

103. Kang HJ, Lee IK, Piao MY, et al. Effects of road transportation on metabolic and immunological responses in Holstein heifers. Anim Sci J 2017;88:140-8.

104. Mills JK, Ross DA, Van Amburgh ME. The effects of feeding medium-chain triglycerides on the growth, insulin responsiveness, and body composition of Holstein calves from birth to $85 \mathrm{~kg}$ of body weight. J Dairy Sci 2010;93:4262-73.

105. Doreau M, Ferlay A. Digestion and utilization of fatty acids by ruminants. Anim Feed Sci Technol 1994;45:379-96.

106. Zinn RA, Gulati SK, Plascencia A, Salinas J. Influence of ruminal biohydrogenation on the feeding value of fat in finishing diets for feedlot cattle. J Anim Sci 2000;78:1738-46.

107. Hess BW, Moss GE, Rule DC. A decade of developments in the area of fat supplementation research with beef cattle and sheep. J Anim Sci 2007:86:E188-204.

108. Jeong J, Hwang JM, Seong NI, et al. Effects of supplemented $\mathrm{PROSOL}^{\oplus}$ as an emulsifier on growth performance and carcass characteristics in Hanwoo steers of final fattening period. J Anim Sci Technol 2009;51:395-406.

109. Nelson DL, Cox MM. Lehninger principles of biochemistry. 5th ed. New Yrok, USA: W.H. Freeman; 2008.

110. Ørskov ER. Starch digestion and utilization in ruminants. J Anim Sci 1986;63:1624-33.

111. Harmon DL, McLeod KR. Glucose uptake and regulation by intestinal tissues: implications and whole-body energetics. J Anim Sci 2001;79:E34-49.

112. Moharrery A, Larsen M, Weisbjerg MR. Starch digestion in the rumen, small intestine, and hind gut of dairy cows - a meta-analysis. Anim Feed Sci Technol 2014;192:1-14.

113. Rowe JB, Choct M, Pethick DW. Processing cereal grains for animal feeding. Aust J Agric Res 1999;50:721-36.

114. Lozano O, Theurer CB, Alio A, et al. Net absorption and hepatic metabolism of glucose, L-lactate, and volatile fatty acids by steers fed diets containing sorghum grain processed as dry-rolled or steam-flaked at different densities. J Anim Sci 2000;78:1364-71.

115. Bindon BM. A review of genetic and non-genetic opportunities for manipulation of marbling. Aust J Exp Agric 2004;44: 687-96.

116. Wood JD, Enser M, Fisher AV, et al. Fat deposition, fatty acid composition and meat quality: a review. Meat Sci 2008;78:34358.

117. Williams JE, Wagner DG, Walters LE, et al. Effect of production systems on performance, body composition and lipid and mineral profiles of soft tissue in cattle. J Anim Sci 1983;57: 1020-8.

118. Gunter SA, Galyean ML, Malcolm-Callis KJ. Factors influencing the performance of feedlot steers limit-fed high -concentrate diets. Prof Anim Sci 1996;12:167-75.

119. Costa ASH, Costa P, Bessa RJB, et al. Carcass fat partitioning and meat quality of Alentejana and Barrosã young bulls fed high or low maize silage diets. Meat Sci 2013;93:405-12.

120. Chung KY, Lunt DK, Kawachi H, Yano H, Smith SB. Lipogenesis and stearoyl-CoA desaturase gene expression and enzyme activity in adipose tissue of short- and long-fed Angus and Wagyu steers fed corn- or hay-based diets. J Anim Sci 
2007;85:380-7.

121. Arnett EJ, Fluharty FL, Loerch SC, et al. Effects of forage level in feedlot finishing diets on carcass characteristics and palatability of Jersey beef. J Anim Sci 2012;90:960-72.

122. Yamada T, Nakanishi N. Effects of the roughage/concentrate ratio on the expression of angiogenic growth factors in adipose tissue of fattening Wagyu steers. Meat Sci 2012;90:807-13.

123. Essen-Gustavsson B, Karlsson A, Lundstrom K, Enfalt AC. Intramuscular fat and muscle fibre contents in halothane gene free pigs fed high or low protein diets and its relation to meat quality. Meat Sci 1994;38:269-77.

124. D'Sousa DND, Pethick DW, Dunshea FR, Pluske JP, Mullan BP. Nutritional manipulation increases intramuscular fat levels in the Longissimus muscle of female finisher pigs. Aust J Agric Res 2003;54:745-9.

125. Li L, Zhu Y, Wang X, He Y, Cao B. Effects of different dietary energy and protein levels and sex on growth performance, carcass characteristics and meat quality of F1 Angus $\times$ Chinese Xiangxi yellow cattle. J Anim Sci Biotechnol 2014;5:21-32.

126. Marino R, Braghieri A, Albenzio M, et al. Effect of rearing system and of dietary protein level on leptin, growth, and carcass composition in young Podolian bulls. J Anim Sci 2009;87: 3097-104.

127. Kawakita Y, Abe H, Hodate K, et al. The relation between plasma leptin concentrations and carcass lipid contents in Japanese Black steers. Livest Prod Sci 2001;73:25-34.

128. Sato M, Hiragun A, Mitsui H. Preadipocytes possess cellular retinoid binding proteins and their differentiation is inhibited by retinoids. Biochem Biophys Res Commun 1980;95:183945.

129. Ohyama M, Matsuda K, Torii S, et al. The interaction between vitamin A and Thiazolidinedione on bovine adipocyte differentiation in primary culture. J Anim Sci 1998;76:61-5.

130. Oka A, Maruo Y, Miki T, Yamasaki T, Saito T. Influence of vitamin A on the quality of beef from the Tajima strain of Japanese Black cattle. Meat Sci 1998;48:159-67.

131. Adachi K, Kawano H, Tsuno K, et al. Relationship between serum biochemical values and marbling scores in Japanese Black steers. J Vet Med Sci 1999;61:961-4.

132. Gorocica-Buenfil MA, Fluharty FL, Bohn T, Schwartz SJ, Loerch SC. Effect of low vitamin A diets with high-moisture or dry corn on marbling and adipose tissue fatty acid composition of beef steers. J Anim Sci 2007;85:3355-66.

133. Pickworth CL, Loerch SC, Fluharty FL. Restriction of vitamin $\mathrm{A}$ and $\mathrm{D}$ in beef cattle finishing diets on feedlot performance and adipose accretion. J Anim Sci 2012;90:1866-78.

134. Oka A. Vitamin A in feeding of beef cattle. Proc Jpn Soc Anim Nutr Metab 1999;43:137-44.

135. Bedo G, Santisteban P, Aranada A. Retinoic acid regulates growth hormone gene expression. Nature 1989;339:231-4.

136. Dalke BS, Roeder RA, Kasser TR, et al. Dose-response effects of recombinant bovine somatotropin implants on feedlot per- formance in steers. J Anim Sci 1992;70:2130-7.

137. Kawachi $\mathrm{H}$. Micronutrients affecting adipogenesis in beef cattle. Anim Sci J 2006;77:463-71.

138. Molotkov A, Fan X, Duester G. Excessive vitamin A toxicity in mice genetically deficient in either alcohol dehydrogenase Adh1 or Adh3. Eur J Biochem 2002;269:2607-12.

139. Ziouzenkova O, Orasaun G, Sharlach M, et al. Retinaldehyde represses adipogenesis and diet-induced obesity. Nat Med 2007;13:695-702.

140. Ward AK, McKinnon JJ, Hendrick S, Buchanan FC. The impact of vitamin A restriction and $\mathrm{ADH} 1 \mathrm{C}$ genotype on marbling in feedlot steers. J Anim Sci 2012;90:2476-83.

141. Ishida Y, Taniguchi H, Baba S. Possible involvement of 1 alpha,25-dihydroxyvitamin D3 in proliferation and differentiation of 3T3-L1 cells. Biochem Biophys Res Commun 1988; 151:1122-7.

142. Hida Y, Kawada T, Kayahashi S, Ishihara T, Fushiki T. Counteraction of retimoic acid and 1,25-dihydroxyvitamin D3 on up-regulation of adipocyte differentiation with PPAR $\gamma$ ligand, an antidiabetic thiazolidinedione, in 3T3-Ll cells. Life Sci 1998; 62:PL205-11.

143. Ji S, Doumit ME, Hill RA. Regulation of adipogenesis and key adipogenic gene expression by 1,25 -dihydroxyvitamin $\mathrm{D}$ in 3T3-L1 cells. PLoS One 2015;10:e126142.

144. Wang B, Yang Q, Harris CL, et al. Nutrigenomic regulation of adipose tissue development-role of retinoic acid: a review. Meat Sci 2016;120:100-6.

145. Smith SB, Kawachi H, Choi CB, et al. Cellular regulation of bovine intramuscular adipose tissue development and composition. J Anim Sci 2009;87:E72-82.

146. Committee on Animal Nutrition, National Research Council. Nutrient requirements of beef cattle. 8th ed. Washington, DC, USA: The National Academies Press; 2016.

147. Rebouche CJ. Ascorbic acid and carnitine biosynthesis. Am J Clin Nutr 1991;54:1147-52.

148. Kawada T, Aoki N, Kamei Y, et al. Comparative investigation of vitamins and their analogues on terminal differentiation, from preadipocytes to adipocytes, of 3T3-L1 cells. Comp Biochem Physiol 1990;96:323-6.

149. Torii S, Matsumoto K, Matsui T, Yano H. Effect of Vitamin A, C and D on glycerol-3-phosphate dehydrogenase activity of sheep preadipocytes in primary culture. Anim Sci Technol (Jpn.) 1995;66:1039-42.

150. Ohashi H, Takizawa H, Matsui M. Effect of vitamin C on the quality of Wagyu beef. Res Bull Aichi Agric Res Center 2000; 32:207-14.

151. Pogge DJ, Hansen SL. Supplemental vitamin C improves marbling in feedlot cattle consuming high sulfur diets. J Anim Sci 2013;91:4303-14.

152. Nathanielsz PW, Poston L, Taylor PD. In utero exposure to maternal obesity and diabetes: animal models that identify and characterize implications for future health. Obstet Gynecol 
Clin North Am 2007;34:201-12.

153. Long NM, Tousley CB, Underwood KR, et al. Effects of earlyto mid-gestational undernutrition with or without protein supplementation on offspring growth, carcass characteristics, and adipocyte size in beef cattle. J Anim Sci 2012;90:197-206.

154. Mohrhauser DA, Taylor AR, Underwood KR, et al. The influence of maternal energy status during midgestation on beef offspring carcass characteristics and meat quality. J Anim Sci 2015;95:786-93.

155. Underwood KR, Tong JF, Price PL, et al. Nutrition during mid to late gestation affects growth, adipose tissue deposition, and tenderness in cross-bred beef steers. Meat Sci 2010; 86:588-93.

156. Radunz AE, Fluharty FL, Relling AE, et al. Prepartum dietary energy source fed to beef cows: II. Effects on progeny postnatal growth, glucose tolerance, and carcass composition. J Anim Sci 2012;90:4962-74.

157. Moisá SJ, Shike DW, Faulkner DB, et al. Central role of the
PPAR $\gamma$ gene network in coordinating beef cattle intramuscular adipogenesis in response to weaning age and nutrition. Gene Regul Syst Bio 2014;8:17-32.

158. Bell AW, Greenwood PL. Prenatal origins of postnatal variation in growth, development and productivity of ruminants. Anim Prod Sci 2016;56:1217-32.

159. Greenwood P, Edward C, Bell A. Developmental programming and beef production. Anim Front 2017;7:38-47.

160. National Institute of Animal Science, Rural Development Administration. Korean feeding standard for Hanwoo. Sejong, Korea: Ministry of Agriculture, Food and Rural Affairs; 2007.

161. Esteve Ràfols M. Adipose tissue: cell heterogeneity and functional diversity. Endocrinol Nutr 2014;61:100-12.

162. Bauman DE, Mellenberger RW, Derrig RG. Fatty acid synthesis in sheep mammary tissue. J Dairy Sci 1973;56:1312-8.

163. Pyatt NA, Berger LL. Review: Potential effects of vitamins $\mathrm{A}$ and $\mathrm{D}$ on marbling deposition in beef cattle. Prof Anim Sci 2005;21:174-81. 